ARCHIWA, BIBLIOTEKI

I MUZEA KOŚCIELNE 111 (2019)

https://doi.org.10.31743/abmk.2019.111.02

JAN BULAK* - KRAKÓW

ANNA MAKARCZYK** - KRAKÓW

\title{
AKTA WIZYTACJI PODKRAKOWSKIEJ PARAFII ZIELONKI Z XVIII WIEKU W ZASOBIE W ARCHIWUM KURII METROPOLITALNEJ W KRAKOWIE
}

\section{Streszczenie}

W niniejszej publikacji autorzy prezentują osiemnastowieczne akta wizytacji podkrakowskiej parafii pw. Narodzenia Najświętszej Marii Panny w Zielonkach. Zabytkowy kościół z XIV wieku (większa część obecnego kościoła pochodzi z XVI wieku) przez lata był zależny od krakowskiej kapituły katedralnej, potem Akademii Krakowskiej (obecnie Uniwersytet Jagielloński) oraz kolegiaty św. Anny. Przybliżone zostały tutaj w formie edycji tekstu źródłowego trzy ostatnie wizytacje parafii Zielonki sprzed upadku Rzeczypospolitej: z 1727 roku (AVCap 61 oraz AV 23), z 1748 roku (AV 29 oraz Tabele Załuskiego 7) i z 1783 roku (AV 55). Księgi tych wizytacji są przechowywane w Archiwum Kurii Metropolitalnej w Krakowie (AKMKr), mieszczącym się przy ul. Franciszkańskiej 3. Wizytacje te, to rękopisy w języku łacińskim oraz polskim $\mathrm{z}$ dużą liczbą zwrotów pochodzących $\mathrm{z}$ łaciny. Wyłącznie Tabele biskupa Załuskiego mają format drukowanego formularza, w którego rubryki odręcznie zostały naniesione stosowne informacje. Celem autorów było dokonanie możliwie wiernej edycji tych źródeł, aby udostępnić je szerszemu gronu odbiorców. Metodologia pracy skupiła się na rozwinięciu skrótów zastosowanych przez pisarzy, uwspółcześnieniu pisowni dla większej czytelności tekstu, a także dodaniu znaków diakrytycznych i znaków interpunkcyjnych w wymagających tego miejscach. Autorzy wzbogacili

* Jan Bulak - mgr historii; doktorant w Instytucie Historii Uniwersytetu Papieskiego Jana Pawła II w Krakowie; e-mail: jaroszy5@op.pl

https://orcid.org/0000-0002-8319-8205

** Anna Makarczyk - mgr historii sztuki; doktorant w Instytucie Historii Uniwersytetu Papieskiego Jana Pawła II w Krakowie; e-mail: a.makarczyk@interia.pl

https://orcid.org/0000-0002-2120-1739 
tekst przypisami tekstowymi, bibliograficznymi i terminologicznymi. Podjęte czynności edytorskie są zgodne z zasadami naukowej edycji źródeł historycznych dla tekstów nowożytnych. W rezultacie autorzy prezentują trzy pełne teksty wizytacji, wraz z inwentarzami, opatrzone wstępem, przypisami oraz bibliografią.

Słowa kluczowe: wizytacja; Akademia Krakowska; parafia Zielonki; kapituła św. Anny; krakowska kapituła katedralna

\section{Wstęp}

Jednym z najważniejszych źródeł umożliwiających opracowanie historii parafii są akta wizytacji. Urzędowe odwiedzanie wspólnot chrześcijańskich znane jest już niemal od IV wieku. Ta forma badania stanu kościołów, ich wyposażenia, gospodarstwa plebańskiego oraz przede wszystkim kontrolowania duchowieństwa i wspólnoty wiernych rozpowszechniła się w Polsce już od XIII wieku i była związana z instytucją sądów synodalnych. Celem sądów było utrzymanie przez zwierzchnika podległego sobie kleru, a także osób świeckich w karności. Największy zwrot w tej dziedzinie przyniósł Kościołowi katolickiemu sobór trydencki (1545-1563), który nakazał m.in. wizytować parafie rokrocznie, a w większych diecezjach - co dwa lata. W I Rzeczypospolitej przepisy soborowe wprowadzono dopiero w 1577 roku i rzeczywiście dość regularnie biskupi i dziekani dokonywali wizytacji kanonicznych, choć rzadziej niż pierwotnie ustalono. Parafię często wizytowali także kanonicy katedralni, tzw. wizytatorzy działający na polecenie biskupa ${ }^{1}$. Do dziś sporządza się raporty z wizyt, zarówno dziekańskich, jak i biskupich, które - deponowane w archiwum - będą stanowić zbiór przydatnych informacji dla przyszłych badaczy.

Wiek XVIII to czas wyjątkowego rozkwitu akcji wizytacyjnej szczególnie w archidiakonacie krakowskim. Kolejni biskupi - Łubieński, Szaniawski, Lipski, Załuski i Sołtyk - dokonywali oględzin licznych kościołów, w tym także podkrakowskiej parafii pw. Narodzenia Najświętszej Marii Panny w Zielonkach. Akta dotyczące Zielonek w tym okresie są dość bogate i dostarczają cennych informacji o parafii $\mathrm{i}$ postaciach $\mathrm{z}$ nią związanych oraz na temat kościoła i jego wyposażenia. Te zagadnienia były dotąd poruszane w pracach naukowych wyłącznie epizodycznie, dlatego autorzy zdecydowali się na udostępnienie szerszemu gronu odbiorców akt trzech osiemnastowiecznych wizytacji parafii Zielonki przechowywanych w Archiwum Kurii Metropolitalnej w Krakowie.

${ }^{1}$ Więcej na ten temat: A.W. Pęski, Wizyta kościelna, w: Encyklopedia kościelna podtug teologicznej encyklopedji Wetzera $i$ Weltego z licznymi jej dopetnieniami, t. 31, Warszawa 1911, s. 534538; J. Kracik, Zasoby Archiwum Kurii Metropolitarnej w Krakowie, „Analecta Cracoviensia”, 9 (1977) s. 471-493; T. Glemma, Wizytacje diecezji krakowskiej z lat 1510-1570, Kraków 1946, s. 2-15; D. Główka, Akta wizytacji kościelnych z wieków XVI-XVIII jako źródto do dziejów historii kultury materialnej. Gospodarstwo wiejskie $w$ dobrach parafialnych $w$ archidiakonacie warszawskim, w: Szkice z dziejów materialnego bytowania społeczeństwa polskiego, „Studia i materiały z historii kultury materialnej”, t. 61, red. M. Dembińska, Wrocław-Warszawa1989, s. 234-235. 
Pierwsza wzmianka o wsi Zielonki, zlokalizowanej ok. $7 \mathrm{~km}$ od krakowskiego Rynku, pochodzi z 1260 roku, kiedy to odnotowano w źródłach śmierć kanonika Alberta, prepozyta łęczyckiego. Przekazał on część wsi krakowskiej kapitule katedralnej². Kościół pw. Narodzenia NMP należałoby datować właśnie na przełom XIII i XIV wieku, natomiast w rękach kapituły parafia pozostawała do 1531 roku, kiedy to została przekazana kolegiacie św. Anny w Krakowie w zamian za kamienicę Zerwikaptur przy ulicy Grodzkiej (obecnie nr 57) ${ }^{3}$. Od tej pory funkcję proboszcza Zielonek pełnił (prezentowany przez Akademię Krakowską) każdorazowo jeden z członków kapituły św. Anny, najczęściej dziekan, a parafia stała się jakby kościołem filialnym krakowskiej kolegiaty. Po zajęciu przez Austrię ziem na prawym brzegu Wisły, w wyniku pierwszego rozbioru Rzeczyspospolitej, proboszczowie kolegiaty św. Anny stracili swoje uposażenie w podkrakowskich Podstolicach. Aby zrekompensować sobie tę stratę, każdorazowo proboszcz parafii pw. św. Anny stawał się równocześnie proboszczem w Zielonkach ${ }^{4}$. Proboszcz rezydował w Krakowie i przyjeżdżał do Zielonek raczej rzadko, zwykle na większe święta ${ }^{5}$. Funkcję wikarego pełnił zatrudniany do pracy na miejscu kapłan, który sprawował curam animarum.

Omawiana parafia należała w wieku XVIII do dekanatu skalskiego. W jej okręgu znajdowały się następujące wsie: Bibice, Garlica, Górka, część Pękowic, Tonie, Witkowice, Wola Zachariaszowska i Zielonki. Granice parafii nie zmieniły się aż do wejścia w życie postanowień Kongresu Wiedeńskiego, w wyniku których Wola Zachariaszowska i część Garlicy zostały przyłączone do zaboru rosyjskiego ${ }^{6}$.

Parafia Zielonki uzyskała niezależność dopiero w 1878 roku, choć prawo prezenty nadal posiadała Akademia Krakowska ${ }^{7}$. Pomimo że po opisanych w poniższych wizytacjach stosunkach nie został już żaden ślad, wciąż w parafii można spotkać relikty kontaktów z krakowską kolegiatą: zarówno w postaci herbów Akademii Krakowskiej w różnych miejscach świątyni, jak i ołtarzy - głównego i dwóch bocznych - pochodzących z 1728 roku. Oprócz tego obecne są wizerunki świętych pańskich, którzy byli związani z kolegiatą, a mianowicie wymieniane w wizytacjach obrazy św. Anny i św. Jana Kantego. Na samym zaś końcu należy wspomnieć, iż obecnie najhuczniej obchodzony odpust parafialny przypada właśnie w niedzielę po święcie św. Anny (choć nie jest to główny odpust), co jest pamiątką tych związków. Niestety, prawie wszystkie drogocenne ruchomości,

${ }^{2}$ Monumenta Poloniae Historica, t. 2, oprac. A. Bielowski, Lwów 1872, s. 807.

${ }^{3}$ Archiwum Uniwersytetu Jagiellońskiego (AUJ), fasc. 301.

${ }^{4}$ Archiwum parafii Zielonki (APZ), Kronika parafialna, t. 1, s. 1.

${ }^{5}$ Tamże, s. 19.

${ }^{6}$ J. Bulak, Duchowieństwo parafii Zielonki (1795-1918), w: XLV Międzynarodowe Seminarium Kół Naukowych „Koła Naukowe - Szkoła Twórczego Działania”, red. M. Gryglik, S. Skiendziul, J.E. Śliczyńska, Olsztyn 2016, s. 45, https://msknolsztyn.files.wordpress.com/2016/09/tom-1-sekcja-humanistyczna-sekcja-teologiczno-kanonistyczno-familiologiczna.pdf (dostęp: 17.04.2017).

${ }^{7}$ Cały proces oddzielania się parafii został, najlepiej jak dotąd, opisany w przytaczanej już kronice parafii: APZ, Kronika parafialna, s. 1-6. 
które są wymieniane $\mathrm{w}$ inwentarzach, przepadły podczas włamania do kościoła w 1846 roku. Przypadkiem ocalały wyłącznie gotyckie paramenty liturgiczne: kadzielnica i łódka ${ }^{8}$, które obecnie znajdują się w Muzeum Archidiecezjalnym w Krakowie.

W Archiwum Kurii Metropolitalnej w Krakowie jest przechowywany bogaty zbiór wizytacji diecezji krakowskiej, liczący łącznie 121 woluminów z okresu staropolskiego: od końca XVI do końca XVIII wieku. W zbiorach tego archiwum znajdują się akta wizytacji parafii Zielonki: z roku 1598 (w dwóch wersjach: sygn. AVCap 15 oraz AVCap 65), dekrety wizytacji z lat 1601-1605 (AV 4), wizytacja z 1610 roku (AVCap 28), 1618 roku (AVCap 38 oraz AVCap 40), 1629 roku (AVCap 42), 1663 roku (AV 8), 1727 roku (AVCap 61 oraz AV 23), 1748 roku (AV 29 oraz Tabl. Załuskiego 7) i 1783 roku (AV 55) ${ }^{9}$. Akta te nigdy nie zostały opublikowane in extenso. Prace dotyczące m.in. Zielonek, z dotąd marginalnym wykorzystaniem tekstów wizytacji, zostały napisane przez Tomasza Markiewicza ${ }^{10}$ i Mateusza Wyżgę ${ }^{11}$. Szerzej z omawianych akt skorzystał Jan Bulak w artykule dotyczącym życia codziennego w parafii Zielonki w XVIII wieku ${ }^{12}$.

W poniższej edycji źródłowej zostały zaprezentowane trzy ostatnie z wyżej wymienionych akt, które ukazują stan parafii Zielonki w XVIII stuleciu. W związku z faktem, iż dwie z nich (akta z 1727 i 1748 roku) zachowały się w dwóch różniących się w szczegółach egzemplarzach, w przypisach tekstowych zaznaczono różnice pomiędzy informacjami zawartymi w obydwu rękopisach. Należy zaznaczyć, iż informacje wizytacyjne z 1748 roku umieszczano na kartach $\mathrm{w}$ formie tabelarycznego zestawienia danych, jednolity tekst natomiast został zapisany $\mathrm{w}$ osobnej księdze. $\mathrm{W}$ formie wykazu w pełni zostały zaprezentowane informacje zawarte w Tabelach biskupa Andrzeja Stanisława Załuskiego. Każda ze 140 rubryk została wypełniona odręcznie. Zawierają one informacje dotyczące usytuowania geograficznego wsi, wyglądu i wyposażenia kościoła parafialnego, dane statystyczne, a także wzmianki o różnych wspólnotach wyznaniowych. Tabele biskupa Załuskiego to jedyne źródło spośród omawianych tutaj akt będące rękopisem wykorzystującym drukowany formularz. Prezentowane wizytacje były pisane $\mathrm{w}$ większości $\mathrm{w}$ języku łacińskim. Wyjątek stanowią inwentarze

\footnotetext{
${ }^{8}$ APZ, Kronika parafialna, s. 18.

${ }^{9}$ Opisu archiwalnego dokonał Bolesław Stanisław Kumor. Zob. Katalog mikrofilmów Ośrodka Archiwów, Bibliotek i Muzeów Kościelnych przy Katolickim Uniwersytecie Lubelskim, nr 4, oprac. B.S. Kumor, Lublin 1975, s. 3-14.

${ }^{10}$ T. Markiewicz, Duchowieństwo dekanatu Skała w świetle wizytacji z 1618 roku, „Archiwa Biblioteki i Muzea Kościelne”, 94 (2010) s. 79-193.

${ }^{11}$ M. Wyżga, Funkcjonowanie wiejskich cmentarzy parafii katolickich $w$ dobie przedrozbiorowej na przykładzie dekanatów Nowa Góra, Skała i Proszowice z okolic Krakowa, „Kwartalnik Historii Kultury Materialnej”, (2014) nr 3, s. 441-461.

${ }^{12}$ J. Bulak, Duchowieństwo parafii Zielonki (1797-1943), w: Wybrane zagadnienia z dziejów Zielonek i Bibic, red. J. Bulak, M. Zieliński, Zielonki 2018, s. 74-101.
} 
sprzętów kościelnych, które pisane były polszczyzną z dużą liczbą naleciałości obcojęzycznych oraz ostatnia przedrozbiorowa wizytacja - z 1783 roku, która została napisana całkowicie po polsku z niewielkimi tylko wstawkami łacińskimi, zwłaszcza w cytatach z Pisma Swiętego ${ }^{13}$.

\section{Zasady edycji}

Edycję tekstu oparto na zasadach podanych w pracy Kazimierza Lepszego Instrukcja wydawnicza dla źródet historycznych od XVI w. do pot. XIX w. ${ }^{14}$ We wszystkich wizytacjach rozwinięte zostały skróty zastosowane przez skrybów, jak na przykład ,-9”, które rozwijano jako „--us”, czy „S. Anna”, którą zapisano jako „Sancta Anna” itp. Starano się modernizować pisownię w miejscach, w których wymagała tego czytelność tekstu, np. zamieniając niepotrzebne wielkie litery na małe, zmieniając „sz” na „,̇” (np. w słowie „łyżka”), ,i, na ,j” lub „g” (,iako” = ,jako"; ,aienda"=,,agenda"), ,ij” na ,ii”(np. w słowie „Evangelii”), a także dodając znaki diakrytyczne i znaki interpunkcyjne w odpowiednich miejsach. Słowa, które nie zmieniają sensu, a są znakomitymi przykładami zasad piśmiennictwa staropolskiego, pozostawiono bez zmian. Wszystkie przypisy pochodzące od edytorów zostały zapisane kursywą, dla odróżnienia od tekstu źródłowego. W przypisach tekstowych - co zostało już zaznaczone - odnotowywano wszelkie uwagi edytorskie co do samego tekstu źródłowego, natomiast w przypisach rzeczowych (terminologicznych) wyjaśniono słowa lub zwroty, które mogłyby się wydawać niezrozumiałymi dla współczesnego czytelnika, a także podano najważniejsze informacje $\mathrm{z}$ życia wspomnianych $\mathrm{w}$ źródle postaci historycznych. W nawiasach kwadratowych zostały zapisane numery kart, na których umieszczony jest dany fragment tekstu. W księdze wizytacji z roku 1727 została na odwrót wszyta karta 29/30, przez co archiwista dokonał niepoprawnej paginacji, co zostało poprawione i zaznaczone w przypisie tekstowym. Na tej samej stronie został wspomniany inwentarz kościoła: Inventarium huius ecclesiae. Nie został on odnaleziony w Archiwum Kurii Metropolitalnej w Krakowie, co pozwala domniemywać, że się nie zachował.

$$
* * * * *
$$

$1727 r$.

AVCap 61, Visitatio archidiaconatus Cracoviensis per illustrissimum et reverendissimum d[om]inum Michaelem de Magna Kunice Kunicki episcopum Arsinoensem, suffraganeum et archidiaconum pro tunc Cracoviensem, annis infrascriptis peracta.

AV 23, Visitatio archidiaconatus Cracoviensis per illustrissimum et reverendissimum d[om]inum Michaelem de Magna Kunice Kunicki episcopum Arsinoensem, suffraganeum et archidiaconum pro tunc Cracoviensem, annis infrascriptis peracta.

${ }^{13}$ Por. Glemma, Wizytacje diecezji krakowskiej, s. 16.

${ }^{14} \mathrm{~K}$. Lepszy, Instrukcja wydawnicza dla źródet historycznych od XVI w. do pot. XIX w., Warszawa 1953. 


\section{[27]}

\section{Zielonki $^{15}$}

$\mathrm{d}[\mathrm{ie}] 16$ septembris

Villa haereditatis S[acrae] R[aegiae] M[aies]t[a]tis, in qua ecclesia parochialis murata tituli Nativitatis B[eatae] V[irginis] M[ariae], iuris patronat[us] Collegii Maioris Almae Universit[a]tis Crac[oviensis] consecrata; dies dedicationis celebratur Dominica 1ma post festum Nativit[a]tis eiusdem B[eatae] V[irginis] $\mathrm{M}[\mathrm{ariae}]^{\mathrm{a}}$. Continens altaria tria: $\underline{\mathrm{m}}[\underline{\mathrm{um}}]^{16}$ maius B.V.M. variis colorib[us] depictum consecratum; $\underline{2 \mathrm{du}}[\underline{\mathrm{m}}]^{17}$ ad cornu Epistolae ${ }^{\mathrm{b}}$ in maiori choro s[ancti] Nicolai desuper s[ancti] Caroli Boromei sparsim deauratum, sparsim nigro colore depictum, huius altaris mensa murata, grad[us] lapide[us] unus; $\underline{3 t i u m}^{18}$ ad cornu Evangeliic $s$ [anctae] Annae sparsim deauratum et depictum. Ciborium in medio maioris altaris extructum, in quo $\mathrm{S}$ [anctissimum] S[acramentu]m in pixide argentea fons et intus deaurata asservatur. Renovatio S[acramenti] S[anctissi]mi sit decima quinta die mensis cuiuslibet ${ }^{19}$. Baptisterium in medio ecclesiae marmoreum positum, nigri coloris, ad quod gradus lapidis albi unus, continens lebetem aeream in parte dealbatam, fontem non adeo limpidum. Turricula eius aerea deaurata et depicta in superficie crux, sera pensili baptisterium clauditur. Piscina ad cornu Evangelii maioris altaris profunda operculo ligneo obturata. Armariolum ad cornu Evangelii maioris altaris in muro excisum ad quod fores ferreae craticulares, sera fixa claudit[ur]. Olea sacra in vasculis stanneis tribus insimul junctis, anno currenti renovata asservantur. Est et aliud seorsivum vasculum stanneum pro oleo infirmorum. Prope hoc armariolum est camera similiter in muro excisa pro asservandis lampadib[us], fores ejus ferreae in medio craticulares sed non clauduntur. Sacrarium in minori choro a cornu Evangelii muratum ad quod fores ferreae depictae, sera firma fixa et pensili clauduntur. In hoc sacrario mensae binae cum suis armariis sat

\section{[28]}

sufficientib[us] pro asservando apparatu, fenestra una, cuius craticulae duae ferreae cum operculo ferreo ex coemeterio, lacunar sacrarii muratum. Scrinium ligneum pro asservandis albis et alio apparatu sera fixa clauditur. Item post fores sacrarii est armarium pro monstratorio et calicib[us] in muro excisum cum forib[us] ferreis sera fixa et pensili optimis claudi[tur $]^{20}$. Aspersorium parvum marmoreum eundo ex sacrario. In minori choro ante maius altare stalla duo lignea bona. In maiori

${ }^{a}$ Odpust parafialny obchodzony jest w pierwsza niedziele po święcie Narodzenia Najświętszej Marii Panny, które przypada 8 września.

${ }^{\mathrm{b}}$ Strona Lekcji, czyli strona prawa.

' Strona Ewangelii, czyli strona lewa.

${ }^{15}$ W oryginale słowo zostało zapisane większa czcionka.

${ }^{16}$ W oryginale wyliczenia $w$ tekście zostaty podkreślone pojedyncza linia, co zaznaczono $w$ tym wydaniu.

${ }^{17}$ W oryginale stowo zostało podkreślone.

${ }^{18}$ W oryginale stowo zostało podkreślone.

${ }^{19} \mathrm{~W}$ rękopisie o sygn. AV 23 zastosowano inny szyk: cuiuslibet mensis.

${ }^{20}$ W oryginale autor napisat końcówkę $\sim$ tur na wymazanym, poprzednim tekście. 
vero choro scamna bona et sufficientia pro commodo parochianorum. Pavimentum in $\mathrm{m}$ [in]ori ${ }^{21}$ choro marmoreum, in medio sepulchrum lapide obturatum ex utraq[ue] parte maioris altaris, et post altare pavimentum ex laterib[us]. In maiori choro pavimentum ex quadrato lapide, a foribus vero ex laterib[us] sub scamnis in maiori choro pavimentum nullum ${ }^{22}$. Lacunar maioris chori orbiculariter muratum cum parietib[us] sat pulchre depictum. In maiori choro tabulatum ligneum bonum $^{23}$. Ambona lignea antiquae structurae. Confessionale unum. Chor[us] ligneus in quo organum octo vocum, aditus ejus ab ecclesia, cuius fores ligneae. Item adinstar altaris est mensa, in qua posita est imago s[anctae] Annae, quae est ad deferendum in processionib[us]. In hac ecclesia est confraternitas s[anctae] Annae, quae nullam dotem habet. Fenestrae ecclesiae novae ac integrae maiores et minores numero septem. Valvae ecclesiae duae: 1 mae a meridie ligneae, cum atrio murato in cardinib[us] sera fixa fores atrii sera pensile. ${\underline{2 d a e^{24}}}$ ad septentrionem similiter ligneae cum atrio ligneo sera fixa et pensili clauduntur. Ecclesia ab extra in suis muris et pertinentiis decera dealbata. Tectum supra minorem chorum ex lateribus, supra maiorem ex scandulis, in medio turricula oblonga valuae. Altera turricula parva in qua signatis, campanile ab occidente ligneum scandulis bene tectum, in quo campanae duae benedictae. Sepimenta coemeterii lignea in parte scandulis spoliata praesertim a domo vicariali. Ossorium in coemeterio ligneum muro ecclesiae innixum, bene tectum. Rector ecclesiae illustris et adm[odum] $\mathrm{r}\left[\right.$ everen]dus $\mathrm{m}$ [agnificus] Francisc[us] Kalewski ${ }^{\mathrm{d}} \mathrm{s}$ [ancte] t[heologiae] professor, collega maior, eccl[esiarum] coll[egiatae] s[anctae] Annae Cracoviae decan[us] ${ }^{\mathrm{e}}$, ss.(sanctorum) apo[stolorum] Philippi et Jacobif ${ }^{\mathrm{f}}$ ad Cracoviam

${ }^{\mathrm{d}}$ Franciszek Kalewski, philosophiae doctor (dalej: PhD) - studiowat sztuki wyzwolone w Akademii Krakowskiej. Nauczyciel różnych przedmiotów, wykładowca Akademii Krakowskiej. Zarówno tam, jak $i$ w strukturach kościelnych petnit szereg funkcji. Jan Szczepaniak podaje, że petnit funkcje plebana w Zielonkach od 2 V 1722 do 1734 roku. Zmart w 1747 roku. (J. Szczepaniak, Duchowieństwo diecezji krakowskiej w XVIII w. Studium prozopograficzne, Kraków 2010, s. 605).

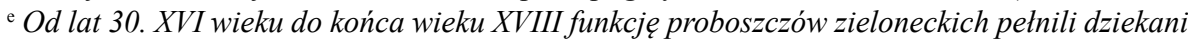
kapituly kolegiaty św. Anny. (Por. J. Szczepaniak, Spis prałatów i kanoników kapituly katedralnej oraz kapitut kolegiackich diecezji krakowskiej (XVIII w.), Kraków 2008, s. 95; tegoż, Spis prepozytów i plebanów diecezji krakowskiej (XVIII w.), Kraków 2008, s. 139).

${ }^{\mathrm{f}}$ Kościót pw. śś. Filipa i Jakuba zostat wzniesiony na terenie Kleparza, miasta leżacego na pótnoc od murów miejskich Krakowa. Kościót ten spłonąt w 1755 roku (nie po raz pierwszy), zostat odrestaurowany, a następnie zburzony w 1801 roku, gdy w Krakowie trwała akcja burzenia nierentownych budynków sakralnych. (M. Rożek, Nie istniejące kościoły Krakowa, „Biuletyn Biblioteki Jagiellońskiej”, 33 (1983) s. 113).

${ }^{21}$ W oryginale środkowe litery wyrazu zostaty wymazane.

${ }^{22}$ W AV 23 zmiana szyku: nullum pavimentum.

${ }^{23}$ W oryginale litery bon... zostaty pogrubione.

${ }^{24}$ W oryginale stowo zostało podkreślone. 
praepositus, qui habet domum plebanalem a tergo ecclesiae ligneam, in qua hypocaustum cum camera et atrio sat sufficientib[us]. Item penes domum plebanalem altera domus pro familiag. Item granarium bonum. Pecuaria sat sufficientia post granarium. Pomarium plebanale circumcirca sepib[us] obductum. Idem illustris rector

$$
[29]^{25}
$$

fovet vicarium, qui adpraesens est adm[odum] r[everen]dus Jacobus Zrzodliński $^{\mathrm{h}}$ phi[losophi]ae baccalaureus, capellae Lauretanae in ecclessia archipresbiteriali altarista ${ }^{\mathrm{i}}$, anno $1721 \mathrm{mo}$ in festo s[ancti] Martini episcopi, die $11^{26}$ novembris ordinat[us] per illustrissimu[m] [Joannem] ${ }^{27} \mathrm{Tarło}^{\mathrm{j}}$, approbationem et applicationem ad eandem ecclesiam produxit, institutus ad altare anno $1721 \mathrm{mo}$, die Lunae 21 Aprilis $^{\mathrm{k}}$, qui habet domum ex opposito forium ecclesiae, bonam scandulis tectam, in qua hipocaustum parvum cum camera atrio et culina. Item fovet organarium, qui habet domum a tergo domus vicarialis et salariatur 20 florenis annuatim, qui et cantoris onus suffert. Dos ecclesiae Zielonecensis. $\underline{\mathrm{mo}}^{28}$ habet agros in libro visitationis Kazimirzcianae ${ }^{1}$ sufficientier $^{29}$ descriptos, quorum est in possesi-

${ }^{\mathrm{g}}$ Tu: dom dla stużby.

${ }^{\mathrm{h}}$ Jakub Albert Zrzodliński (Zrudlinski, Zrodlinski) PhD - ksiąz diecezji krakowskiej, przyjąt święcenia prezbiteratu 10 IX 1721, wikariusz w Zielonkach i proboszcz w Lętkowicach, gdzie zmart w 1748 roku. (J. Szczepaniak, Katalog duchowieństwa diecezjalnego zestawiony na podstawie krakowskich ksiag święceń (1646-1789), t. 4, Kraków 2009, s. 1347; tegoż, Spis prepozytów i plebanów, s. 84).

${ }^{i}$ Kaplica św. Wawrzyńca w kościele Mariackim została zbudowana w latach 1423-1441 z funduszy rajcy krakowskiego Marka Noldenfessera. Kaplica zwana jest także kaplica Mazarakich, od obywateli krakowskich, którzy w XIX wieku uczynili z kaplicy swoje rodowe mauzoleum. (M. Rożek, Przewodnik po zabytkach i kulturze Krakowa, Kraków 1993, s. 216).

j Jan Joachim Tarto herbu Topór PhD, sanctae theologiae doctor (dalej: SThD) - ur. 1658 w województwie sandomierskim, syn Jana i Anny z Czartoryskich, brat Michała Barttomieja. Po studiach w Krakowie w 1694 roku zostat mianowany kanonikiem, a po jedenastu latach zostat archidiakonem krakowskim, a także kanonikiem poznańskim. Profesor teologii w Bydgoszczy (1686-1687) i filozofii w Lublinie (1687-1689). Po dymisji z zakonu jezuitów w 1718 otrzymat biskupstwo kijowskie. 15 III 1723 przeniesiony do biskupstwa poznańskiego, które objąt w czerwcu tegoż roku. Tam odbudowat zniszczona katedre poznańska. Tarto byt także asystentem tronu papieskiego. Zmart 13 VIII 1732 w Wiedniu. (P. Nitecki, Biskupi Kościoła w Polsce w latach 965-1999, Warszawa 2000, s. 444; Encyklopedia wiedzy o jezuitach na ziemiach Polski i Litwy 1564-1995, oprac. L. Grzebień, Kraków 1996, s. 683).

${ }^{\mathrm{k}}$ Ttum. W poniedziałek.

${ }^{1}$ Chodzi o wizytacje prepozyta tarnowskiego Krzysztofa Kazmierskiego przeprowadzona za rzadów biskupa krakowskiego Jerzego Radziwiłta w 1598 roku. (Zob. Archiwum Kurii Metropolitalnej w Krakowie (AKMKr), AVCap 15, s. 24).

${ }^{25}$ W oryginale, na skutek złego wklejenia karty, strona oznaczona jest jako 30.

${ }^{26} W$ AV 23: undecima.

${ }^{27}$ W AV 23 zapisano także imię: Joannem.

${ }^{28}$ W oryginale stowo zostato podkreślone.

${ }^{29}$ W oryginale ostatnia litera zamazana przez kleks. 
one. $\underline{\text { Item }}^{30}$ habet decimam manipularem ex agris praedialib[us] Marszowiec ${ }^{\mathrm{m}}$ dictis. Item ${ }^{31}$ habet aliam decimam manipularem ex agris praedialibus et cmethonalibus villae Magnae Garlica ${ }^{\mathrm{n}} .{ }^{*}$ Item $^{32}$ habet decimam manipularem ex agris praedialibus et cmethonalibus villae Pękowice ${ }^{\circ}$ alternatim cum parocho Giebulthoviensi $i^{\mathrm{p}}$. Pro confessione paschali numerantur personae circiter 800 . Ad parochiam pertinent villae Zielonki, Tonie, Bibice, Witkowice, Górka, Garlica, Wola Zacharyaszowska et Pękowice. Inventarium huius ecclesiae videatur folio...

\section{Decretum reformationis}

Quemadmodum in ante crevit augmentu[m] cultus Divini in ecclesia parochiali Zielonecensi, ita et adpraesens sub regimine illustris et adm[odum] r[everen]di Francisci Kalewski s[anctae] t[heologiae] profess[oris] et crescere non desinit. Proinde solummodo annuitur, quatenus pulveres in maiori choro ecclesiae intra scamna existens saltim pavimento ligneo tegantur. Fons baptismalis mundius servetur. Minister ecclesiae diligenter circa apparatum ecclesiasticum et sobri[us] habea[tur]. Decima manipularis ex praedio villae Pękowice utrum pars quae nunc percipitur tantum an vero integra, assistente sibi iure communi administrationis sacra[men]t[orum] suae ecclesiae debeatur diligens discussio ad tollendum ambiguitatem etiam litigiosa, prout decreto immediatae visitat[io]nis iniunctum fuerat, adhibeatur. Et quoniam decima ex agro Biechowa ${ }^{q}$ vocitato in villa Zielonki sito, similiter ex molendino Rozdziałowskie ${ }^{r}$ dicto nemini extraditur nec ulla gratitudo intuitu administrationis sacramentorum exhibet[ur], recomendatur, ut eandem [deci] $\mathrm{mam}^{33}$ assistente sibi iure communi requirat, cathalogum

${ }^{\mathrm{m}}$ Marszowiec - wschodnia część wsi Zielonki, zwana wcześniej także Idzikowicami. W XVIII wieku Marszowiec byt własnościa królewska. (W. Bukowski (red.), Marszowice, w: Stownik historyczno-geograficzny województwa krakowskiego w średniowieczu, cz. 4, z. 1, Kraków 2006, s. 166; dalej SHG).

${ }^{n}$ Garlica - wieś leżąa na pólnoc od Zielonek. Część należata do krakowskiej kapituly katedralnej, zaś część była własnościa szlachecką. Dziś dzieli się na Garlicę Murowana i Duchowna. (Z. Leszczyńska-Skrętowa, Garlica Dolna, w: SHG, oprac. J. Laberschek, Z. Leszczyńska-Skrętowa, F. Sikora, J. Wiśniewski, cz. 1, z. 4, Wrocław 1986, s. 707-709).

o Pękowice - wieś leżąca na zachód od Zielonek. Własność szlachecka. (Stownik geograficzny Królestwa Polskiego i innych krajów stowiańskich, red. F. Sulimierski, B. Chelbowski, W. Walewski, t. 8, s. 36-37; Warszawa 1880-1914; dalej SG).

${ }^{\mathrm{p}}$ Giebultów - wieś leżaca na pótnocny-zachód od Zielonek, z własnym kościotem parafialnym. Tamtejsza parafia graniczy z Zielonkami w podzielonych na pót Pękowicach. (Z. Leszczyńska-Skrętowa, Giebołtow, w: SHG, cz. 1, z. 4, s. 726-730).

${ }^{\mathrm{q}} \mathrm{Na}$ obecnym etapie badań nie potrafimy określić, gdzie znajdowata się ta ziemia.

${ }^{\mathrm{r}}$ Rozdziałowskie - część wsi Zielonki, zlokalizowana przy drodze głównej prowadzacej do Krakowa, niedaleko (ówczesnej) wsi Prądnik Biały. Oprócz zabytkowego mlyna stojącego nad rzeka Białucha (Prądnikiem) znajduje się tam kapliczka z 1646 roku.

${ }^{30} \mathrm{~W}$ oryginale stowo zostato podkreślone.

${ }^{31}$ W oryginale stowo zostato podkreślone.

${ }^{32} \mathrm{~W}$ oryginale stowo zostato podkreślone.

${ }^{33}$ W oryginale skrót: Xmam. 
confirmatorum parochianorum tempore connota[ti]onis pro confessione paschali organario conscribere demandet caetera zelo et nitori reliquntur. $\mathrm{R}$ [everen]dus vero vicari[us] doctrinam catechisticam diebus Dominicis prout consuevit non intermittat. Diem nativitatis infantum in libro baptisatorum annotet. In quorum fidem et[c] datum ut supra.

$1748 r$.

Tabl. Zal. 7, Tabellae ecclesiarum. Decanatus: Prossoviensis, Plesnensis, Ropczycensis, Strzyzoviensis, Scalensis et Vitoviensis.

Zielonki, 20 Juliii ${ }^{34}$.

Villa Zielonki.

[nr 83]

Tabella eorum, super quibus in visitatione inquirendum est. ${ }^{35}$ Oppidum seu villa: Villa Zielonki S[acrae] Raegiae Maiestatis.

Archidiaconatus: Cracoviensis.

Officialatus: Cracoviensis.

Decanatus: Skalensis.

Palatinatus: Cracoviensis.

Terra seu Districtus: Cracoviensis.

Capitaneatus: Cracoviensis.

Oppidum vicinum versus Orientem: Słomnikis duobus milliaribus.

Versus meridiem: Cracovia metropolis uno milliari.

Versus occidentem: Oppidum Nowa Gorat tribus milliaribus.

Versus septemtrione[m]: Oppidum Skała ${ }^{u}$ duobus milliarib[us].

Distantia Cracovia: Uno milliari.

Distantia Kielciis: Quindecim milliaribus.

Distantia ab Officio Foraneo: Duobus milliaribus.

' Stomniki - miasto królewskie leżace na pótnocny wschód od Zielonek nad rzeka Szreniawa, granicza z nim Brańczyce (Brończyce), Kẹpa, Niedźwiedź, Prandocin i Łaganowice. (Z. Leszczyńska-Skrętowa, Brańczyce, w: SHG, cz. 1, z. 4, s. 208).

${ }^{\mathrm{t}}$ Nowa Góra - wieś (do I wojny światowej miasto) leżaca na zachód od Zielonek. Król Władysław Jagietto nadat ja kasztelanowi krakowskiemu Janowi z Tęczyna wraz z wsiami. (F. Sikora, Góra Nowa, w: SHG, cz. 1, z. 4, s. 828-829).

"Skata - miasto na pótnoc od Zielonek nad rzeka Pradnik. Własność księcia krakowskiego Bolesława Wstydliwego, który ofiarowat ją dla zakonu sióstr klarysek przybyłych z Zawichostu (województwo sandomierskie). (J. Laberschek, Grodzisko, w: SHG, oprac. J. Laberschek, Z. Leszczyńska-Skrętowa, F. Sikora, cz. 2, z. 1, Wrocław 1989, s. 72).

${ }^{34}$ W oryginale data podkreślona dwukrotnie.

${ }^{35}$ W oryginale fraza wydrukowana nad tabela, powiększona czcionka. 
Ecclesia: Tota murata, in minori choro tabulatum muratum in maiori ligneum.

Erectio: Non est, et libris tantum retaxationum beneficiorum iura conquiruntur.

Titulus: Nativitatis B[eatissi]mae Mariae Virginis.

Consecratio: De consecratione, quo anno fuerat consecratio non constat, tamen ex visitationibus tam Oborsciana, qua[m] Kazimirsciana scribunt esse consecratam.

Dies dedicationis: $\mathrm{D}$ [omi]nica prima post festum Exaltationis $\mathrm{S}[\mathrm{an}] \mathrm{ct}[\mathrm{i}]$ Crucisv.

Iuspatronatus: Collegii maioris Univeritatis Cracovien[sis].

Altare maius: B[eatissi]mae Virg[inis] Mariae Assumptae, mensa lapidea consecrata. Ligneum in parte deauratum, in parte depictum novum a[nn]o 1728 consecratum.

Ciborium: Ligneum arte sculptore laboratum in partibus deauratum et in parte depictum, in quo conservatur $\mathrm{S}[$ anctis $] \mathrm{s}[\mathrm{i}] \mathrm{mu}[\mathrm{m}]$ Sacramentum in pixide argentea.

Lampas ante S[anctissimum] S[acra]m[ent]um: Tempore devotionis solet ardere.

Olea sacra: Conservanti in pariete chori minoris a parte Evangelii occlusa cratula ferrea, in vasculis stanneis simul iunctis.

Reliquiae: Non reperiuntur.

Indulgentiae: Reperiuntur et indulto Romano a[nn]o 1741 Romanorum obtentae ad decenniu[m] indulgentia plenaria pro festo Nativitatis $\mathrm{B}$ [eatissi]mae V[irginis] Mariae tum pro sex festitatibus B[eatissi]mae septem annorum et totidem quadragenae, et ab officio admissae.

Altaria collateralia: Duo. A parte Evangelii ligneum s[anctae] Annae in parte deauratum in parte depictum cum mensa lapidea depictum, altera vetus $\mathrm{s}$ [ancti] Nicolai ex parte epistolae.

Imago gratiosa: Non reperitur.

Sacrarium: Muratum a cornu Evangelii cum armariis pro supellectili ecclesiastica fenestra una cum craticula ferrea et cum porta bene occlusa ferrea.

Inventarium rerum sacrarum: In seorsivo Regestro productum.

Tabella obligationu[m]: Non reperitur.

Anniversariorum: Nulla anniv[e]rsa[ria].

${ }^{\mathrm{v}}$ Rocznica poświęcenia kościoła obchodzona była w pierwsza niedziele po święcie Podwyższenia Krzyża, które przypada na 14 września. Należy zwrócić uwage na niezgodność z wizytacja z 1727 roku, gdzie napisano, iż dies dedicationis obchodzi się w niedziele po Święcie MB Siewnej (8 IX). Faktycznie dzień ten obchodzony byt w niedzielę po 14 IX i zwyczaj ten praktykowano jeszcze w latach 40. XX wieku. 
Divinorum officioru[m]: Quolibet festo est $\mathrm{D}$ [omi]nica matutinum, post corona[m] s[anct]ae Annae tum etiam de Immaculata conceptione B[eatae] $\mathrm{V}$ [irginis] Mariae officium festis contio in d[omi]ni[c]is cathehismus et missa conventualis.

Confessionalia: Unum in choro maiori ligneum commodum.

Scamna: Lignea vetera tam in maiori choro quam in minori.

Liber baptizatorum: $\mathrm{Ab}$ a[nn]o 1655 sine defectu ad a[nnum] 1703; in 2do ab anno 1703 ad an[num] 1744 sine defectu; 3tio ab a[nn]o 1745 ad an[num] [1]748 ad[que] 15 Julii sine defectu.

Copulatorum: $\mathrm{Ab}$ a[nno] $1656 \mathrm{ad}$ an[num] 1706; in 2do libro ab a[nn]o 1707 ad an[num] 1744; in 3tio ab an[no] 1745 ad an[num] 1748 ad[que] 14 Julii.

Mortuorum: In primo libro ab a[nn]o $1714 \mathrm{ad}$ an[num] 1744 sine defectu; in $2 \mathrm{do} \mathrm{ab}$ an[no] $1745 \mathrm{ad}$ an[num] $1748 \mathrm{ad}$ [que] 16 Julii sine defectu.

Fundamenta ecclesiae: Murata et iam circumducta muro vulgo skarpa.

Parietes: Murati in minori choro misteriis B[eatissi]mae depicti.

Fenestrae: Tres in minori choro et tres in maiori ex parte occidentali omnes integra in plumbo.

Fornix: Non est.

Tabulatum: Assericium in maiori choro non depictum in minori latericium seu muratum.

Pavimentum: In minori choro marmoreum, in maiori partim ex lapide quadrato, partim latericium.

Portae: Duae una maior ab occidente cum ligneis foribus et seris pensilibus altera minor a parte meridionali cum foribus ligneis.

Porticus: Duae ante minorem portam et ante maiorem ligneae scanduli tectae.

Tectum: Ex scandulis bonum in maiori choro in minori vero tegula tectum.

Turricula cum campana: Lignea vetus et in alio loco pro campana est constructum tectum, nam haec turricula ob vetustatem non potest sustinere campanam.

Campanile: A parte ecclesiae ligneum assericium indiget reparatione.

Campanae: [D]uae, maior et minor dicuntur esse benedictae in maiori $\mathrm{e}$ [st] effigies crucifixi et $\mathrm{B}$ [eatissi]mae V[irginis] Mariae et $\mathrm{s}$ [anctorum] Stanislai et Adalberti 1616 comparatae, in minori Beati Joannis Cantii 1723 a[nn]o comparatum.

Caemeterium: Sepimentis assericiis circumductum et scandulis in parte tectum.

Ossuarium: A parte parietis eccl[esi]ae ligneum ex operibus scandulis tectum.

Sumptus fabricae: Non sunt. Tantum ex proventibus parochiae.

Villae ad parochiam: Septem. Zielonki, Tonie, Pękowice de una parte, Garlica, Wola Zacharyaszovska, Bibice, Witkowice et Górka.

Confessi pro paschate: Nongenti octaginta unus. 
Missio: De missione non constat.

Domus rectoris: Lignea post eccl[esi]am a parte septentrionali commoda scandulis tecta.

Vicariorum: Distincta domus vicarialis a facie eccle[si]ae a parte occidentali eccl[esi]ae commoda, scandulis tecta intus in parte parietum indiget reparatione.

Praebendariorum: Non est.

Concionatoris: Non est.

Promotoris Confraternitatis: Non est.

Organarii: Extra coemeterium lignea scandulis tecta in parte indiget reparatione.

Cantoris: Non est.

Magistri Scholae: Non est.

Sacristiani: Non est.

Domus pro familia: Est a parte distinctim in domo rectoris commoda scandulis contecta intus etiam indiget reparatione.

Stabularium vulgo obora: Iunctim pro domo famulae ligneum in parte maiori reparatum de novo.

Equile: Ligneum scandulis contectum, commodum.

Horreum: Unum commodum, non indiget reparatione.

Granarium: Supra equile ligneum scandulis tectum et pro frumento commodum.

Pomarium: Est districtum a domo rectoris in adeo amplum arboribus tamen fructiferis plenum.

Hortus olitorius: Insimul cum pomario coniunctus, sulcorum 28.

Apiarium: Alvearia reperiuntur tria.

Columbarium: Non est.

Praedium: Non est.

Subditi seu inquilini: Sunt septem. Un[us] in septimana duos dies laborat, alii vero per unum pedester.

Agri: In libro visitationum seorsim descriptiw.

Prata: Est pratum exiguum sed saepe cessius aquis circumfunditur.

Sylva: Non est.

Stagna Piscinae: Non sunt.

Molendinum: Non est.

Propinatio: Est et percipit 200 florenos arendae ${ }^{36}$ curialis $^{37}$ tenet et propinationem praedialem in Zielonki esse tenutarius.

Census: Non reperintur.

Decima manipularis seu missalia: Decimae vero ex villa Tonie et sunt tribus ex agris praedialibus tantum. 2do ex mediis agris curialibus villae

${ }^{\mathrm{w}}$ Por. AV 29, s. 99v lub czytaj poniżej, w niniejszej edycji.

${ }^{36} \mathrm{~W}$ oryginale pierwotnie zapisano ab arendatore, co nastęnie przekreślono i zmieniono na arendae.

${ }^{37}$ W oryginale wyraz poprzedni poprawiony $w$ sposób nieczytelny. 
Zielonki, ita quibusdam hortulanis. Ex curia Pękovien[si] ex illis agris, qui sunt adiacentes illorum et ex villa Garlica Nobilis.

Decima pecuniaria: Decimam peccuniariam ex villa Bibice florenos 160 percipit.

Legata: Nulla sunt adpraesens.

Inventarium oeconomicum: Seorsive descriptum.

Proventus annuus praeter propter: Mille ducentos florenos computando cum expensis, quae sunt notabiles.

Decima mensae episcopalis: Nulla.

Decima in parochia: Ex Górka ill[ustrissi]mi suffrag[anei] Cracovien[sis], ex Tonie et Witkowice ad ill[ustrissi]mu[m] cap[i]tu[lum] Crac[oviense], ex Zielonki ad prae[posi]turam s[ancti] Stephani, ex Pękowice ad Giebułtów, ex Wola Zacharyaszowska ad vicarios arcenses ${ }^{\mathrm{x}}$.

Intra annum baptizat[orum]: Hoc est a[nn]o 1747 reperiuntur in libro metrices 66.

Desponsati: Hoc est a[nn]o 1747. 11.

Sepulti: Hoc est a[nn]o 1747. 38.

Adulti masculi: 471.

Adultae faeminae: 306 .

Infantes masculi: 206.

Infantes faemellae: 188 .

Monasteria virorum: Non sunt.

Monasteria monialiu[m]: Non sunt.

Capellae: Capella una reperitur in Witkowice murata sub titulo s[anctae] Mariae Magdalenae pertinet ad peraug[ustum] cap[itu]lum Crac[oviense] uti villa praestimonialis.

Oratoria privata: Non sunt.

Ecclesiae ritus graeci: Non sunt.

Fana dissidentium: Non sunt.

Synagoga Judaeorum: Non sunt.

Graeco uniti: Non sunt.

Schismatici: Non sunt.

Judaei: In Zielonki quatuor in arenda braxatoriarum et in Garlica Nobilium quinque.

Luterani: Non sunt.

Calvinistae: Non sunt.

Rector ecclesiae: Ill[ust]ris et adm[odum] r[evere]ndus Adalbertus Grzymała $^{y}$ sa[nct]e th[eolog]i[a]e doctor et prof[essor] collega maior.

× Tu: wikariusze katedry krakowskiej na zamku wawelskim.

y Wojciech Ludwik Grzymała PhD, SThD - ur. 1672 w Tracku, uczyt się w Reszlu, studiowat w Akademii Krakowskiej. Pelnit szereg funkcji kościelnych i naukowych w Akademii Krakowskiej (m.in. dziekan wydziałów Teologicznego i Filozoficznego). Proboszcz w Zielonkach (31 II 17351752). Zmart 21 V 1767 (Szczepaniak, Duchowieństwo diecezji krakowskiej, s. 593). 
Aetas: Annos 51.

Origo: Ex palatinatu Cracoviens[i] districtu Biecenisi de genere nobili.

Ordinatio: Ordinatus ad presbyteratum a[nn]o $1735 \mathrm{ab}$ ill[ustrissi]mo Michaelo Kunicki ${ }^{\mathrm{z}}$ suff[raganeo] Crac[oviense].

Assecutio beneficii: Institutus etiam a[nn]o 1735 ad hocce beneficium.

Educatio in seminario: Tempore ordinationum.

Studia in seminario: Humaniora tractavit Crosnae apud PP. Soc[ietas] Jesu, theologiam et philosophiam in Universitate Crac[oviensi].

Beneficia: Decanus s[anctae] Annae, custos s[ancti] Georgii in arce Cracovien[si] et curatus in Zielonki, quae beneficia sunt incorporata ad Universitatem Cracovien[sem].

Approbatio: Approbatus anno 1747 ad decursum trium annorum.

Recollectiones: Tempore ordinationum explevit.

Congregatio decanalis: Solet adesse vel per[sonali]te[r],vel per vicarium.

Residentia: Juxta ordinationem ill[ustriss]imi olim Petri Tomickia in Collegio Maiori Universitate Cracoviensis.

Libri: Non sunt annexi ad eccl[esi]am, iam autem graduale, antiphonarum et alii pro commodo cantus eccle[si]ae reperiuntur.

Subsidiu[m] charitativu[m]: Annuatim solvit per duas rathas florenos 51 et $\mathrm{g}[\mathrm{rossos}] 20$ alias pro una ratha flor[enos] 25 et gros[sos] 25 .

${ }^{\mathrm{z}}$ Michat Kunicki herbu Bończa-ur. 7 X 1698 w Czulicach koło Chetmna. Od 23 X 1726 biskup sufragan i oficjat generalny $w$ Krakowie. Kunicki pracowat w parafii $p w$. Wniebowzięcia NMP $w$ Książnicach i parafii pw. św. Katarzyny Dziewicy i Męczennicy w Drużbakach Dolnych. Kanonik prebendy Gorecka (Górka), prebendy Doiazdowska (Dojazdów), prebendy Raciborska (Raciborowska). Kustosz sandomierski (5 IX 1725-1751), kantor wiślicki (9 IV 1750-1751). Zmart 9 XI 1751. (Szczepaniak, Katalog parafii, s. 2; tenże, Spis prałatów i kanoników, s. 13, 16, 21, 30, 47; tenże, Spis prepozytów i plebanów, s. 154, 233; tenże, Nekrologium. Księża diecezji krakowskiej zmarli w latach 1749-1810, Kraków 2010, s. 99).

aa Piotr Tomicki herbu Łodzia juris utriusque doctor (dalej: JUD) - ur. 1464 w Tomicach pod Stęszewem, syn Mikołaja i Anny Szamotulskiej. Uczyt się w szkole katedralnej w Gnieźnie, na uniwersytetach w Lipsku i Wiedniu oraz Akademii Krakowskiej, gdzie uzyskat bakalaureat w 1490 roku, a trzy lata później magisterium sztuk wyzwolonych. Studiowat także w Bolonii, gdzie uzyskał stopień doktora obydwu praw. Po ukończeniu studiów zostat kanclerzem kardynała Fryderyka Jagiellończyka, a po jego śmierci biskupa poznańskiego Jana Lubrańskiego. Byt sekretarzem na dworze króla Zygmunta Starego. Wyświęcony na prezbitera w 1511 roku. Od 1514 roku biskup przemyski, od 1520 - poznański, a od 1524 - krakowski. Po śmierci Jana Laskiego w 1531 roku Tomicki odrzucit stolice prymasów, która zaproponowat mu król. Wybitny humanista (korespondowat z Erazmem z Rotterdamu), mecenas (wybudowat murowane dwory biskupie m. in. w Kielcach i Bodzentynie), opiekun braci studenckiej (utworzyt na Akademii w Krakowie Katedrę Prawa Rzymskiego). Erygowat kolegiaty w Bobowej i Krakowie, a także kilka nowych parafii, np. w Siedlcach. W 1529 roku na jego polecenie opracowano Księge dochodów diecezji krakowskiej, tzw. Acta Tomiciana. Zmart 29 X 1535 w Krakowie i pochowany zostat w katedrze na Wawelu, w ufundowanej przez siebie kaplicy św. Tomasza Kantuaryjskiego. (B.S. Kumor, Dzieje diecezji krakowskiej do roku 1795, t. 1, Kraków 1998, s. 511-512; Nitecki, Biskupi Kościoła, s. 451-452). 
Vicarii: Vicarius unus fovet per applica[tio]nem et est adpr[aes]ens r[everendus] Stanislaus Antoszowicz ${ }^{\text {ab }}$, qui immediate, tempore hujus visitationis, fuerat pariter per applica[tio]nem penes eccl[esi]am in Goszcza ${ }^{\text {ac }}$.

Praebendarii: Non sunt.

Promotor confraternitatis: Non sunt.

Concionator: Tum rector eccl[esi] ae, tum vicarius.

Organarius: Mathias Konieczkiewicz post mortem patris iam per sex annos commorat, sobrius et diligens in officiis ecclesiasticis.

Cantor: Non est.

Magister scholae: Non sunt.

Sacristianus: Non est.

Vitrici seu provisores: Non sunt.

Scholares: Aliqui reperiuntur in villa, quos informat organarius.

Devote seu eremitae: Non sunt.

Obstetrices: Reperiuntur in villis ad parochiam sex, quae sunt instructae proferre formam baptismi in necessitate.

Hospitale: Non est.

Fundatio: Non est.

Pauperes: Reperiuntur non, nulli in villis.

Ecclesia hospitalis: Non est.

Capellanus: Non est.

\section{$1748 r$.}

AV 29, In nomine Domini. Amen. Visitatio ecclesiarum parochialium, praebendarum, capellarum, hospitalium, confraternitatum, nec non beneficiatorum in decanatu Scalensis foraneo, dioecesis, archidiaconatus et officialatus Cracovien[sis] existentium, ex speciali mandato celsissimi principis excell[entissi] mi illus[trissi]mi et reve[ren]d[iss]imi domini, d[omini] Andreae Stanislai Kostka comitis in Załuskie Załuski, dei et Apostolicae Sedis gratia episcopi Cracoviensis ducis Severiae, per me, Andream Nehrebecki STh. doctorem, insignis colle[gia]tae Sandomiriensis canonicum et scholasticum Scarbimiriensem delegatum et deputatum extraordinarium visitatorem. Anno Domini 1748 die 23 mensis aprilis inchoata ac successive anno eodem 1748 die 24 decembris finita.

ab Stanisław Antoszowicz (Antaszewic, Antoszowic) - ur. 1681 w Krakowie, od 20 XII 1710 roku petnit posługę wikarego w kościele parafialnym pw. Wszystkich Świętych w Goszczy. (J. Szczepaniak, Katalog parafii i duchowieństwa diecezji krakowskiej 1748, Kraków 2006, s. 86).

ac Goszcza - wieś leżaca na pótnocny-wschód od Zielonek nad rzeka Goszcza (prawy dopływ Szreniawy) będąca w posiadaniu kapituly krakowskiej. (J. Laberschek, Goszcza, w: SHG, cz. 1, z. 4, s. 811). 
[97v]

\section{VILLA ZIELONKI ${ }^{38}$}

Status modernus ecclesiae parochialis in villa Zielonki die 21 Julii anno 1748 descriptus ${ }^{39}$.

Ecclesia parochialis in villa S[acrae] R[aegiae] Maiestatis Zielonki sita, murata, supra minorem chorum tegula, supra maiorem scandulis contecta, testudineata in minori choro, in maiori tabulatum asseritium bonum. Ex visitationibus Casimirsciana et Oborsciana constat, quod sit consecrata, ac ex signis antiquis, alias zacheuszkid in pari-

\section{[98]}

etibus depictis. Haec ecclesia est tituli Nativitatis B[eatissi]mae Mariae Virginis, dies dedicationis hujus ecclesiae celebrari solet dominica prima post festum Exaltationis Sanctae Crucis. Ius praesentandi ad eandem vigore donationis illius seu incorporationis per $\mathrm{r}[$ evere]nd[issi]mum capitulum Cracoviense de anno 1531, die veneris 23. Junii factae, et per ill[ust]r[issi]mum olim Petrum Tomicki episcopum Cracoviensem, Regni Poloniae vicecancellarium approbatae, spectat ad collegium maius Universitatis [Studii] Generalis Cracoviensis, quae ecclesia dicitur esse incorporata decanatui ecclesiae collegiatae sanctae Annae Cracovien[sis]. In hac ecclesia altare maius B[eatissi]mae Mariae Virginis ligneum, mensam habens muratam, consecratam, in anno 1728 constructum, arte partim arcaria, partim sculptorea efformatum et depictum, cum ciborio ligneo depicto, in quo Sanctissimum Sacramentum in pixide argentea, intus tantum et circa labia deaurata, operculo simili, cruce parva insignito, ac vesticula sericea obsito clausa, asservatur. Est et ad aliud vasculum argenteum pro deferendo Sanctissimo ad infirmos. Lampas coram eodem Sanctissimo tantum tempore devotionis solet ardere. Altare secundum in maiori choro a parte Evangelii ligneum de novo constructum et depictum ac in parte deauratum. Imago sanctae Annae, mensa eiusdem altaris murata consecrata, huic altari adstant statuae sancti Casimiri et beati Joannis Cantii. Altare tertium, ex opposito huius, sancti Nicolai episcopi

\section{[98v]}

et desuper sancti Caroli Boromaei imagines praeseferens, pariter ligneum, cum mensa consecrata, murata, gradus ad haec altaria de lapide comparati. Baptisterium in medio ecclesiae de marmore nigro efformatum, super lapideo gradu locatum, in quo lebes aeneus dealbatus intus, cum aqua benedicta, operculo aeneo, antiquus ${ }^{40}$ deaurato tegitur, ac sera pensili clauditur. Piscina post maius altare reperitur. Olea sacra ad cornu Evangelii maioris altaris, in armariolo in muro excusso, craticula ferrea ac clusura proviso, in vasculis tribus stanneis simul

${ }^{\text {ad }}$ In. krzyże apostolskie. Ryte, malowane, drewniane lub metalowe krzyże przytwierdzone do ścian kościoła, w miejscach, które podczas konsekracji (tzw. dedicatio) namaścit biskup.

${ }^{38}$ W oryginale wyrazy zostały wyróżnione bardzo duża czcionka.

${ }^{39}$ W oryginale wyraz zostat wyróżniony duża czcionka.

${ }^{40} \mathrm{~W}$ oryginale: antiquius. 
iunctis, continentur. Pavimentum ecclesiae in maiori choro partim de lapide secto, partim lateritium, in minori autem marmoreum. Ambona seu suggestus in maiori choro ligneus, antiquus, penes quem confessionale, scamna lignea ex utraq[ue] parte, colore rubro depicta. Chorus musicus ligneus supra portam maiorem ecclesiae, in quo organum maioris formae alias pozytyw ${ }^{\text {ae }}$, vocum octo, noviter reparatum, adinvenitur. Sacrarium in maiori choro a parte Evangelii muratum, concameratum, ferreis foribus, *rubro colore depictis, clauditur ${ }^{41}$, in quo sunt mensae duae cum armariis et armariolis antiquoribus ${ }^{42}$, pro asservanda supellectili ecclesiastica ac armarium pro asservanda argenteria. Fenestrae in ecclesia hac octo, fores alias valvae ad ecclesiam duae, primae maiores a meridie cum porticu murata, sera tam fixa, quam pensili provisae, secundae ad septemtrionem similes cum atrio seu porticu murata. Coemeterium sepimentis asseritiis circumductum. Ossarium in coemeterio intra parietes muratos ecclesiae, ligneum, scandulis novis contectum. Campanile ab occidente, asseribus veterioribus obductum, reparatione indiget

\section{[99]}

in hoc campanili reperiuntur campanae duae, maior et minor. Maior 1616 [anno] cum effigiebus crucifixi Domini, sancti Stanislai et sancti Adalberti, minor 1723 [anno] beati Joannis Cantii ex aere fusae dicunturq[ue] esse benedictae. Item est in summitate tecti ecclesiae campanula parva alias signans in turricula deformi, crucem inflexam habenti, lamina ductili in sua summitate contecta. Haec ecclesia habet confraternitatem sub titulo sanctae Annae, sed absq[ue] dote, tantum ex devotione populi, corona de eadem sancta Anna diebus festis solet decantari, respectu cuius confraternitatis sunt ${ }^{43}$ indulgentiae pro festo sanctae Annae plenariae ${ }^{\text {af }}$. Item aliae indulgentiae seorsim anno 1741 [anno] pro festo titulari Nativitatis B[eatissi]mae Mariae Virginis pariter plenariae, ac pro festis quatuor eiusdem $\mathrm{B}$ [eatissi]mae septem annorum et totidem quadragenarum huic ecclesiae a $\mathrm{Sa}$ [ncta] Sede Apostolica concessae. Ordo devotionis talis observari solet, diebus dominicis et festis, matutinum, quo finito corona de sancta Anna vel officium parvum de B[eatissi]ma Maria Virgine decantatur, tandem contio vel cathehismus praedicatur ac missa conventuali devotio continuatur. Sub hac parochia extat in bonis praestimonialibus r[evere]nd[issi]mi capituli Cracoviensis

\footnotetext{
ae Pozytyw, czyli przenośne organy, stosunkowo mate, wyposażone w piszczałki i klawiaturę, czasem także i pedat.

${ }^{a}$ Odpust bractwa obchodzony we wspomnienie św. Anny, które przypada na 26 lipca. Można go byto uzyskać po uprzednim wpisaniu się do bractwa, przystapieniu do spowiedzi i komunii św. $i$ odśpiewaniu specjalnej koronki. Członkowie bractwa ponadto mieli za zadanie tożyć datki na światto do kościoła i specjalne ubiory brackie. W każdy wtorek sprawowano mszę z funduszu bractwa za fundatorów, podobnie raz w miesiącu i podczas Suchych Dni odprawiano mszę za zmarlych z bractwa. Specjalne nabożeństwa odprawiano także w Dzień Poświęcenia Kościoła $i$ we wtorek po Suchych Dniach (APZ, Xiażka bracka św. Anny w Zielonkach, R. P. MDCCLXXXV, s. 1).

${ }^{41}$ W oryginale autor napisat te frazy na wymazanym poprzednim tekście.

${ }^{42} W$ oryginale: antiquioribus.

${ }^{43}$ W oryginale wyraz dopisany później.
} 
Witkowice dictis, capella murata sub titulo sanctae Mariae Magdalenae. Rector huius ecclesiae est ill[ust]ris et adm[odum] r[evere]ndus Adalbertus Grzymała in Universitate G[enera]li Cracoviensi s[anctae] th[eologi]ae doctor et professor, collega maior, ecclesiarum collegiatarum s[ancti] Georgii in arce custos et sanctae Annae

\section{[99v]}

Cracoviae decanus, annorum 51, ordinatus ad sacrum presbyteratus ordinem anno 1735. Institutus ad hocce beneficium in Zielonki a[nn]o 1735, die Iovis 31, mensis Martii, in officio v[enerabilis] consistorii g[e]n[era]lis Cracoviensis. Haec beneficia ut pute custodia, decanatus ac parochialis, sunt incorporata Academiae Cracoviensi.

\section{Proventus ecclesiae in Zielonki ${ }^{44}$}

Haec ecclesia habet pro dote: primo agros plebanales in duobus locis positos, et quidem in primo loco unum stadium post hortum plebanalem, inter viam ad villam Tonie, et agrum possesionis $\mathrm{r}$ [evere]nd[issi]mi capituli Crac[oviensis], in secundo loco habet agrum de praedio Zielonecensi regali, Marszowiec dicto, per Serenissimum Augustum II Regem Poloniae, ecclesiae huic vigore privilegii Varsaviae die 25, Junii anno MDCC, regni vero illius anno III datati et ad acta castri Cracovien[sis] sabbato post dominicam Conductus Paschae 1704, per oblatam porrecti, donatum, qui ager a septemtrione est contiguus horto plebanali, protenditurq[ue] inter fluvium Prądnik ab occidente et ab oriente inter prata praestimoniorum peraugusti capituli Cracovien[sis] Zielonecen[sis] et Witkowicen[sis], in longum ad quatuor stadia ovaliter, in latum vero ad medium stadium in villa Zielonki dicta iacen[tes], quae descriptio quo ad situationem agri huius ex privilegio suprascripto est desumpta. Item habet pratum inter campos Witkowicenses et Zielonecenses

\section{[100]}

iacens, sed propter crebras illius inundationes, parvum fructum feni de illo colligit. Item habet decimas manipulares, primam ex agris omnibus praedialibus villae Tonie, quam actualiter percipit in manipulis, et propriis curribus curialibus ad horrea plebanalia conducitur. Notandum, quod haec decima in commutationem agrorum intra fines villae Tonie consistentium, quae ecclesia Zielonecensis inante possidebat, per $r$ [ever]ndum capitulum Crcovie[nse] vigore compromissi in anno 1694 die 30 Octobris, ut instrumentum publicum legalis Alberti Krzyzanskiag notarii apostolici edocet, ecclesiae huic parochiali est cessa ac applicata. Alteram

ag Wojciech Krzyżański - kapłan diecezji krakowskiej. Byt proboszczem w Lipnicy Wielkiej, a także prepozytem św. Jakuba na krakowskim Kazimierzu. 10 XII 1700 roku mianowany na kanclerza kancelarii katedralnej przez sufragana krakowskiego Kazimierza Łubieńskiego. Zmart przed 1749 rokiem. (Szczepaniak, Spis prepozytów i plebanów, s. 323; Kumor, Dzieje diecezji krakowskiej, t. 1, s. 568).

${ }^{44}$ W oryginale fraza wyróżniona większymi literami, a także wyśrodkowana. 
habet decimam, quam pariter in manipulis percipit de medietate praedii regalis in Zielonki Marszowiec dicti, quae similiter per curiam dictam Marszovicensem ad horrea plebanalia conduci solet. Tertiam decimam percipit ex praedio capitulari Zielonecensi integram et ab uno cmethone, qui pro nunc Małek ${ }^{\text {ah }}$, nuncupatur, et haec pariter ad horrea plebanalia curribus eiusdem curiae et cmethonis convehitur. Quartam similiter habet decimam et actualiter eandem percipit a hortulanis villae Zielonki, qui habent agros exdivisos ex agris curialibus praefati praedii regalis, ac ipsam iidem hortulani ad horrea plebani comportant, vel convehunt, quintam percipit decimam in manipulis ex medietate praedii villae Pękowice ex illis agris, alias, qui sunt adiacentes agris Zielonecensibus.

\section{[100v]}

Sextam itidem decimam percipit in manipulis ex agris villa Garlica possesionis nobilium et a subditis eorundem. Item habet decimam ex agris praedialibus et scultetialibus, /ut visitatio Oborsciana possessionem probans adnotat ${ }^{\mathrm{ai}} /$ manipularem in villa Bibice, sed ad praesens nonnisi florenis 160 redimitur. Item habet pomarium prope coemeterium et domum plebanalem cum aliquibus arboribus fructiferis, in quo etiam extat hortus olitorius. Item apiarium cum alveariis ecclesiae legatis tribus. Item habet subditos alias inquilinos septem, quorum unus duos dies, reliqui vero sex, unum tantum diem pedester in septimana laborant. Item rector ecclesiae habet domum plebanalem ligneam, pro sui commoditate, quae est scandulis tecta. Penes quam est residentia pro familia alias piekarnia etiam scandulis tecta, sub tecto eodem eiusdem residentiae est braxatoreolum vetus cum aliquibus necessariis, ad usum propinationis faciendae, hanc autem propinationem modernus rector ecclesiae ex rationibus suis ad praesens sub nomine suo non facit, sed illam in arendam dimittit, quae in domuncula seu parva taberna non procul a residentia vicariali et organariali distanti ad propinandum in ante per parochum loci constructa, per inqulinum ${ }^{45}$ catholicum exercetur, ac solvitur annuatim ex hac taberna per florenos 200. Item est domus pro vicario lignea, scandulis tecta in bono statu a fronte maioris portae consistens, vicarius ad praesens per applicationem officii ordinarii penes hanc ecclesiam fovetur, item domun-

\section{[101]}

culam pro organario extra coemeterium, ex opposito domus vicarialis iacentem. Item rector ecclesiae habet circa domum plebanalem ac in atrio eiusdem domus aedificia ad oeconomiam spectantia. Villae ad parochiam

ah Na obecnym etapie badań nie udało się odnaleźć więcej informacji o wspomnianej osobie. Nazwisko to jest częste w Zielonkach również obecnie.

ai Zob. $A K M K r, A V 8$, s. 127.

${ }^{45}$ W oryginale autor napisat to stowo na wymazanym poprzednim tekście. 
spectant: Zielonki, Tonie, Pękowice miedietas, Garlica, Wola Zacharyaszowska, Bibice $^{46}$, Witkowice, et Górka. Confessi hoc anno pro Paschale 981. Inventarium supellectilis ecclesiasticae et oeconomicae ad finem libri videatur fol[io] 60 .

[60]

\section{Inwentarium ecclesiae in Zielonki ${ }^{47}$ Srebro ${ }^{48}$}

Monstrancja srebrna w promienie słoneczne miejscem wyzłacane, na wierzchu krzyżyk i świat ${ }^{\text {aj }}$ wyzłacany.

Puszka cum operculo pro conservatione Sanctissimiak intus ${ }^{\text {al }}$ pozłocista, ab extra $^{\text {am }}$ tylko po części, na wierzchu krzyżyk.

Puszka mniejsza cum operculo et ${ }^{\text {an }}$ patena srebrna, intus et circa labia ${ }^{\text {ao }}$ pozłocista.

Kielichów srebrnych 4, 1 wielki intus wyzłocony, ab extra pstro złocisty i 3 pomnieysze intus wyzłocone.

$\mathrm{Z}$ patenami srebrnemi ab extra wyzłoconemi.

Krzyż srebrny uszko w pośrodku urwane 1 , na nim effigies Crucifixi ${ }^{\text {ap }} i$ czterech ewangelistów $\mathrm{z}$ aniołkami wyzłacanemi, w którym extant quaedam reliquiae .

Turybularz ${ }^{\text {aq }}$ srebrny z czterema łańcuszkami i 2 kółkami srebrnemi, do niego łódka i łyżka srebrne.

Wotów srebrnych variae formae w serce robione 5 .

Tabliczka w kwadrat srebrna, na której effigies B[eatae] V[irginis] Mariae.

Numizma srebrne wyzłacane.

Koronka na obrazie N[ajświętszej] M[arii] Panny srebrna pozłocista.

Miesiącar pod nogami srebrny.

Korali większych z kołkiem srebrnym, między któremi i paciorki srebrne nici 3. Korali większych sznurków 2

aj Tu: złota kula, która wyobraża glob ziemski - świat.

${ }^{a k} Z$ wieczkiem/przkrywka do przechowywania konsekrowanych komunikantów.

al Ttum. Od wewnatrz.

am Ttum. Na zewnątrz.

an Ttum. Z przykrywka i.

ao Ttum. Wewnatrz i dookoła krawędzi.

ap Thum. Wizerunek Ukrzyżowanego.

aq Trybularz, in. kadzielnica, czyli paramentum liturgiczne, stużące do okadzania wonnościami.

ar Tu: półksiężyc.

${ }^{46} W$ oryginale pierwotnie zapisano niepoprawna nazwe miejscowości: Babice, następnie pisarz dokonat poprawki.

${ }^{47}$ W oryginale fraza wyróżniona większymi literami, a także wyśrodkowana.

${ }^{48}$ W oryginale stowo wyróżnione większymi literami, a także wyśrodkowana. 
[61]

Korali mniejszych z trzema paciorkami srebrnemi nitek 2.

Korali średnich różnych nici 10.

Korali małych nici 5, u jednej nitki krzyżyk srebrny.

Koralików bardzo drobnych nitek 4.

\section{Cyna, mosiądz ${ }^{49}$}

Vasa pro oleis sacris ${ }^{\text {as }}$ cynowe cum trina distinctione $e^{\text {at }}$.

Vasculum pro oleo infirmorum cum operculo ${ }^{\text {au }}$ cynowe.

Ampułek cynowych z miseczką para 1.

Lichtarzy cynowych średnich 6.

Item $^{\text {av }}$ lichtarzy mniejszych 4.

Dzbanuszki cynowe 2. Miseczka na sól święconą.

Lawaterz ${ }^{\text {aw }}$ cynowy z miednicą.

Lichtarzy mosiężnych większych 4.

Lichtarzyk mosiężny mały 1.

Lampa mosiężna przed ołtarzem ś[więtego] Mikołaja.

Lamp blaszanych 3 .

Turybularz mosiężny, łódka i łyżeczka blaszane.

Kociołek mosiężny ad aspersionem ${ }^{\text {ax }} \mathrm{z}$ obłączkiem ${ }^{\text {ay }}$.

Miednica mosiężna średnia 1.

Passyjka ${ }^{\text {az }}$ mosiężna.

Dzwonków małych przy ołtarzach sied[e]m, u kabzule ${ }^{\text {ba }} 1$.

\section{Ornaty $^{50}$}

Ornatów białego koloru 10 cum suis requisitis ${ }^{\mathrm{bb}}$.

Czerwonego koloru 6 cum suis requisitis.

Zielonego koloru 3 cum suis requisitis.

Fioletowego koloru 7 cum suis requisitis.

Czarnego koloru 5 cum suis requisitis.

as Ttum. Naczynie na oleje święte.

${ }^{\text {at }}$ Tlum. Z potrójnym pasem.

au Ttum. Naczynie liturgiczne na oleje do namaszczenia chorych z pokrywka.

av Ttum. Również, także.

aw In. umywalnia, miejsce i sprzęt do obmywania rąk przed rozpoczęciem liturgii.

ax Ttum. Do kropienia [wiernych].

ay Tu: uchwyt do trzymania.

az Pasyjka, in. krucyfiks, czyli krzyż z wyobrażeniem ukrzyżowanego Jezusa Chrystusa.

ba Tu: wieżyczka nad kościołem, in. sygnaturka.

bb Ttum. Z należytościami.

${ }^{49}$ W oryginale fraza wyróżniona większymi literami, a także wyśrodkowana.

${ }^{50} \mathrm{~W}$ oryginale fraza wyróżniona większymi literami, a także wyśrodkowana. 
Stoła ad baptisandum ${ }^{\text {bc }}$ biało błękitna bombowa ${ }^{\text {bd }}$.

Kap różnego koloru z materyi jedwabnych ${ }^{\text {be }} 5$.

Velów ${ }^{\text {bf }}$ białego koloru 10.

Zielonego koloru 3.

Czarnego koloru 2.

Czerwonego koloru 5.

Fioletowego koloru 4.

Do tych velów są burse ${ }^{\text {bg }}$ y pale ph $^{\text {bh }}$

Korporałów $^{\text {bi }}$ sztuczkowych $^{\text {bj }} \mathrm{z}$ koronkami 18.

Item. Korporałów bez koronek 3.

Puryfikaterzów $^{\text {bk }}$ różnych 51 .

Alba rąbkowa ${ }^{\text {bl }} \mathrm{z}$ koronami wielkiemi ${ }^{\text {bm }}$ wrocławskiemi 1.

Alb sztuczkowych 2, u 1 korony szerokie.

[62]

Alb płótna podgórskiego z koronami prostemi 4.

Humerałów ${ }^{51}$ wszystkich $^{\text {bn }} 11$.

Obrusów lnianego płótna jedwabiem krajami wyszywanych 2.

Item. Obrusów lnianych z koronkami 9.

Tuwalni ${ }^{\text {bo }}$ rąbkowych sześć. 2 po krajach złotem wyszywane.

Drugie 2 złotem i jedwabiem wyszywane.

Trzecie 2 jedwabiem wyszywane z koronkami.

Tuwalni sztuczkowych jedwabiem po krajach wyszywanych 9.

bc Ttum. Stuła przy udzielaniu chrztu.

bd Zapewne chodzi o stute z rozszerzonymi, kloszowymi końcami (od fr. bombardes) lub tez o stute wykonana z bombazynu (od fr. bombasine), czyli bawetnianej tkaniny z dodatkiem jedwabiu.

be Jedwab, czyli delikatna tkanina otrzymywana z kokonu jedwabnika - motyla nocnego, potyskujaca i gładka.

bf Welony, czyli zastony z ozdobnych tkanin do przystrojenia kościoła. Także welony na okrycie monstrancji lub welony naramienne noszone przez celebransa podczas przenoszenia Najświętszego Sakramentu.

bg Bursa, czyli sztywna torebka do zanoszenia wiatyku chorym.

bh Zapewne chodzi o palki, czyli kwadratowy i usztywniony materiat, którym nakrywa się kielich lub też paletkę, czyli metalowa blaszke przyszywana do tkanin.

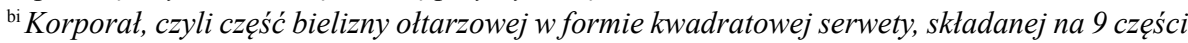
z naszytym krzyżem, najczęściej czerwonym, na środkowym polu.

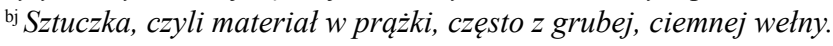

${ }^{b k}$ Puryfikaterz, in. ręczniczek. Czesść bielizny ottarzowej w formie biatego, prostokatnego pasa stużąca do czyszczenia sprzętu liturgicznego po Komuni Świętej.

${ }^{\mathrm{bl}}$ Rąbek, czyli cienka tkanina z lnu.

${ }^{\text {bm }}$ Tu: duże koronki, dla odróżnienia matych koronek.

${ }^{\text {bn } H u m e r a t, ~ c z y l i ~ b i a t a, ~ p r o s t o k a t n a ~ c h u s t a ~ z a k t a d a n a ~ n a ~ s z y j e ̨ ~} i$ ramiona kaptana $z$ dwoma sznurkami do przewiąania na piersiach.

bo Tuwalnia, czyli szeroki pas cienkiej $i$ zdobnej tkaniny. Dawniej tak określano welon naramienny.

${ }^{51}$ W tekście oryginalnym wyraz zapisany przez „,ch”: Chumerał. 
Item. Tuwalnia sztuczkowa z koronami 1.

Item. Tuwalni lnianych z białym szyciem 24 .

Item. Tuwalni lnianych gładkich 19.

Ręczników drelichowych ${ }^{\text {bp }} 3$.

Ręczników małych sztuczkowych jedwabiem wyszywanych 9.

Item. Ręczników lnianych jedwabiem wyszywanych 3, a gładki 1.

Komża lniana z koronkami 1.

Komeżek dla chłopców 2.

Pas czerwony jedwabny 1 .

Item pasów włóczkowych czerwonych 2, błękitnych 2 .

Biretów ${ }^{\mathrm{bq}}$ starych 3.

Antepedyów ${ }^{\text {br }}$ różney materyi y koloru 9.

Item antepedyów skórzanych w kwiaty złote wybijane ${ }^{\text {bs }} 2$.

Item antepedium na drzewie malowane $\mathrm{u}$ wielkiego ołtarza.

$\mathrm{Kabzul}^{\text {bt }}$ ad infirmos 3.2 jedwabnych. Trzecia materyalna półjedwabna.

Fartuszków 3: rąbkowy, sztuczkowy y lniany z koronkami.

Item fartuszków różney materyi y koloru 5.

Tabernakulum axamitne żółte, scabellum ${ }^{\text {bu }}$ takież z galonem srebrnym.

Item tabernaculum materialne czerwone, $\mathrm{z}$ kolumną niebieską lamową.

Sukienek pro pixide $\operatorname{San}[\mathrm{c}] \mathrm{tissimi}{ }^{\text {bv }} 4$.

Firanek do ołtarzy różney materyi i koloru par 15.

Umbracula $^{\text {bw }}$ podczas expozycyi Sanctissimi ${ }^{\text {bx }} 3$ pierwsze w kwiaty srebrne po bokach z komponką ${ }^{\text {by }}$ złotą.

Drugie materyalne białe, trzecie w kwiaty szyte.

Sukna czerwonego 2 do ołtarzy na scabella.

[63]

Item na ambonę szkotowe ${ }^{\mathrm{bz}}$ czerwone $\mathrm{z}$ galonkiem marcypanowym.

Oppon $^{\text {ca }}$ na ołtarze na Wielki Post 3.

Kap brackich szkotowych 3, kapturów 2. Ite[m] lnianego płótna $31^{52}$

bp Drelich, czyli mocna i gruba tkanina wetniana, a czasem lniana.

bq Biret, czyli nakrycie głowy osób duchownych, o kolorze zależnym od stopnia $w$ hierarchii kościelnej. Może mieć trzy lub cztery rogi, a także i wetniany pompon.

${ }^{b r}$ In. antepedium, frontale, czyli bogato zdobiona zastona, zakrywajaca przód mensy oltarzowej. Może to być tkanina, a także obraz, np. na drewnianym podobraziu.

bs Tu: nanoszenie wzoru na tkaninie.

bt Tu: kapsutka, bursa.

bu Ttum. Podnóżek, taboret.

bv Ttum. Na puszkę, w której przechowywany jest Najświętszy Sakrament.

${ }^{\text {bw }}$ Umbraculum, czyli specjalna parasolka liturgiczna, petniaca rolę baldachimu.

bx Tu: Najświętszy Sakrament.

by In. kompanka, czyli wąskie wstawki koronek.

${ }^{\mathrm{bz}}$ Szkot, czyli lekka tkanina pótwetniana z dodatkiem lnu lub bawetny.

ca Tu: opończe, zastony.

${ }^{52}$ W oryginale druga sylaba stowa i liczba ...tna 31 dopisane poniżej. 
Chorągiew adamaszkowa ${ }^{\mathrm{cb}}$ czerwona stara.

Item chorągiew materyalna żałobna.

Item chorągiewek małych na materyi różney z obrazami 6 .

Obrazów brackich 2. 1 ś[więtej] Anny. Drugi Nay[świętszej] Maryi Panny

Częstochowskiey.

Item obraz Nay[świętszej] Panny Częstochowskiey na blasze ${ }^{c c}$.

Obrazów różnych na ścianach w kościele 36.

Baldachim materyalny czerwony $\mathrm{z}$ frandzlą czerwoną, laski malowane.

Krucyfixów większych do procesyi 2.

Passyek na ołtarze z korpusami mosiężnemi 3.

Lichtarzy drewnianych czerwono malowanych y niemalowanych 8 .

Poduszek $^{\text {cd }}$ na ołtarze pod mszały ${ }^{\text {ce }} 5$.

Żelaza ${ }^{\text {cf }}$ na hostye 1 . Cyrkularz ${ }^{\mathrm{cg}} 1$.

\section{Księgi $^{53}$}

Mszał z pokrowcem, indexem ${ }^{\text {ch }}$ jedwabnym.

Mszałów ordynaryjnych ${ }^{\text {ci }} 4$. Regwialnych ${ }^{\text {cj }} 3$.

Agendyck wielkie 2 i mała 1.

Książek brackich 2 in folio.

Graduał $^{\mathrm{cl}}$, antyfonarz ${ }^{\mathrm{cm}}$, psałterz ${ }^{\mathrm{cn}}$, ewangeliki ${ }^{\mathrm{co}}$.

\footnotetext{
${ }^{\mathrm{cb}}$ Adamaszek, czyli jedwabna tkanina z matowym wzorem na blyszczącym tle, a z drugiej strony blyszczacym wzorem na tle matowym.

${ }^{\mathrm{cc}}$ In. ryngraf.

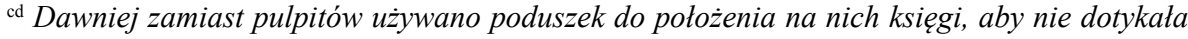
bezpośrednio mensy ottarzowej.

ce Mszal, czyli najważniejsza księga liturgiczna zawierająca teksty statych $i$ zmiennych części Mszy.

${ }^{\mathrm{cf}}$ Tu: specjalne piece, $w$ których wypiekano hostie z mąki pszennej.

cg Tu: okragła forma do wypiekania hostii.

${ }^{\mathrm{ch}}$ Indeks, czyli wstązka, petniaca rolę zaktadki.

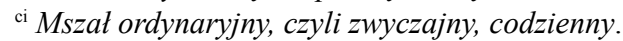

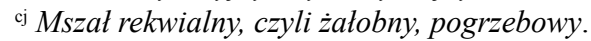

${ }^{\mathrm{ck}}$ Agenda, czyli księga zawierająca przepisy odnośne do sprawowania nabożeństw i udzielanych błogosławieństw.

${ }^{\mathrm{cl}}$ Graduat, czyli kodeks muzyczny zawierajacy śpiewy mszalne.

cm Antyfonarz, czyli zbiór antyfon (najstarszych śpiewów liturgicznych), a także śpiewów używanych poza liturgia.

${ }^{\mathrm{cn}}$ Psatterz, czyli oddzielna księga będąca zbiorem 150 pslamów biblijnych, używana $w$ czasie liturgii.

${ }^{c o}$ In. ewangeliarz, księga zawierajaca tylko perykopy ewangeliczne odczytywane w czasie Mszy.

${ }^{53}$ W oryginale stowo wyróżnione większymi literami, a także wyśrodkowane.
} 


\section{Inwentarz gospodarski ${ }^{54}$}

Krów 2, jałowica 1, pług ze wszystkiemi żelazami 1 , radło ${ }^{\text {cp }} 1$, bron z g[w]oździami 2. Wóz kowany z drabinami.

Reliqua plenius cum descriptione inwentarii, penes ecclesiam sunt relicta ${ }^{\mathrm{cq}}$.

\section{$[101 \mathrm{~cd}]$}

\section{Ordinatio pro ecclesia parochiali in Zielonki 1748 die 23 Julii $^{55}$}

Boni pastoris exemplo in omnibus procedere videtur ill[ust]ris adm[odum] $r[$ evere]ndus Adalbertus Grzymała in Universitate Generali Cracoviensi $\mathrm{sa}[\mathrm{ncta}] \mathrm{e}$ th[elogi]ae doctor et professor, collega maior, ecclesiarum collegiatarum sancti Georgii in arce custos et sanctae Annae Cracoviae decanus, huius loci ab anno 1735 rector, satis enim bene ovile sibi concreditum custodit ne lupi voracis invasione in aliquo laedatur, et non tantum bona custodia commendatur pastor hujus ovilis, sed et quod circa illud omnem servet decorem et munditiem, plurimum laudis habet, ita, ut vere pastor bonus et sedulus vocari mereatur. Et licet personis honore et titulo doctorali, in ecclesia Dei excellentibus bonisq[ue] pastoribus, non sit necesse ordinationes imponere, nihilominus ea, quae sub tempus visitationis nostrae animadvertimus, haec memoriae.

Ill[ust]ris et adm[odum] r[evere]ndi loci huius rectoris insinu-

\section{[101v]}

andum et praeponendum censuimus. Sanctissimum Eucharistiae sacramentum ut quolibet mense bis renovetur et corporalia duo in ciborio sub pixidem ponantur. Suggestus in ecclesia veterioris formae et structurae, ut elegantius emineat cum tempore curabit. Campanile a parte inferiori in asseribus, ne magis desoletur, animadvertet. Aspersorium aliud penes portam maiorem ecclesiae haberi procurabit. Vicarium suum modernum noviter ecclesiae applicatum, ut omnem modestiam ac exemplaritatem servet, cum parochianis in accidentibus ecclesiam concernentibus, observata epistola pastorali in omni affabilitate, et salvo respectu personarum minus valentium ac miserabilium componat, admonebit r[evere]ndum Laurentium Kędzierzawski $i^{\text {cr }}$ nunc vicarium ut dicitur circa ecclesiam in Magna $\mathrm{Xiąz}^{\mathrm{cs}}$, qui non expirato tempore suae applicationis, ante nostram visitationem

${ }^{\mathrm{cp}}$ Radło, czyli narzędzie rolnicze, pierwotnie drewniane, a potem i żelazne, wykorzystywane do robienia bruzd w ziemi i spulchniania gleby.

cq Ttum. Pozostate petniejsze [dokumentacje] z opisaniem inwenatrza sa pozostawione przy kościele.

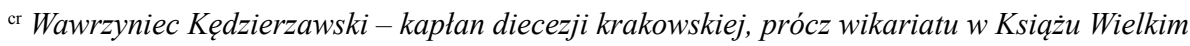
petnit postuge proboszcza w Kossowie (1760-1778), gdzie zmart 30 III 1778 roku (Szczepaniak, Spis prepozytów i plebanów, s. 71).

${ }^{\mathrm{cs}}$ Książ Wielki - miasto na pólnoc od Miechowa, leżace wówczas w diecezji krakowskiej, w dekanacie księskim. (J. Kurtyka, Książ Wielki, w: SHG, red. F. Sikora, cz. 3, z. 3, Kraków 2000, s. 291-313).

${ }^{54}$ W oryginale fraza wyróżniona większymi literami, a także wyśrodkowana.

${ }^{55}$ W oryginale fraza wyróżniona większymi literami, a także wyśrodkowana. 
temere abhac ecclesia recessit, tum Joannem Ochotnicki ${ }^{\text {it }}$, qui per unam tantum septimanam circa hanc ecclesiam commoratus fuerat, plurima vero scandala perpetraverat, contra quos parochiani queretas suas coram nobis exposuerunt, instigatori officii ordinarii ad faciendam ipsorum ad iudicium adcittationem, ne culpa ex male gesto illorum vicariali officio contra se aliquando redundare possit deferat. Proventus ecclesiae quorum alienatonis notitiam habere poterit et respective decimam de agris praedialibus et scultetialibus villae Bibice $^{56}$, quae adpresens post factam cum antecessore composi-

\section{[102]}

tionem nonnisi 160 florenis redimitur, tum vecturam decimarum, quae non habetur in possesione secundum consvetudinem aliarum villarum, vel etiam ut propriis subditis villae ubi locantur huiusmodi decimae, quae ad plebanatum non convehuntur, frumenta ex decimata triturentur, omni meliori modo etiam iure vindicabit. Iudaeos sub parochia existentes, ne dies festos per coctionem cerevisiae et cremati distillationem violare, et ne famulos catholicos in ipsorum braxatoriis commorantes, inquantum ab inquilinatu cum ipsis arceri non possent ad labores hos diebus festivis adigere, ipsiq[ue] famuli aliquos labores sustinere praesumant, invocata etiam curiarum authoritate, serio admoneri faciet, ac in casu recalcitrationis suis mandatis, tam nobilem administratorem, sub cuius dispositione dicti Iudaei permanebunt et adpraesens permanent, quam ipsosmet Iudaeos ac catholicos, instigatori officii ordinarii ad adcittandum, pro sumendis poenis, deferri memoriae tenebit. In reliquo pastoralis ulterior devota vigeat solicitudo, et sic mercedem bonis pastoribus a domino praeparatam, lucrabitur decretumq[ue] praesens in proxime futura congregatione decanali producat. Datum in plebanatu Zielonecensi, anno, die, mense quibus supra.

\section{$1783 r$.}

AV 55, Protokuł wizyty generalney z dekanatów skalskiego i nowogurskiego z rozrządzenia J. O. Xcia Imci Michała Jerzego Poniatowskiego biskupa płockiego koadiutora z zupełną władzą biskupstwa krakowskiego w roku 1783 odprawioney przez W. Jm. X. Stanisława Ptaszyńskiego D. S. T. kanonika katedralnego inflanckiego, proboszcza Nowego Miasta Korczyna.

\section{[27]}

\section{ZIELONKI $^{57}$}

Wieś w województwie i powiecie krakowskim, od Krakowa trzy ćwierci mile, od Kielc mil 15 położona w odległości; ma kościół długości 42, szerokości łokci 16 , bez wiadomości od kogo wymurowany pod

\footnotetext{
${ }^{c t}$ Przy obecnym stanie badań trudno ustalić jego życiorys.

${ }^{56}$ W oryginale niepoprawna nazwa miejscowości: Babice.

${ }^{57}$ W oryginale wyraz zapisany dużymi literami powiększona czcionka.
} 


\section{[28]}

tytułem Narodzenia Najświę[tszej] Maryi Panny, bez wiadomości od kogo, konsekrowany jednak, jako upewnia w roku 1440 Liber beneficiorum ${ }^{\mathrm{cu}}$, i obchodzi się uroczystość w niedzielę po święcie podwyższenia Świętego Krzyża w jesieni. Ten [kościół] szkarpami opasany, opadłymi nieco z tynku, wnijścia ma dwoje: wielkie spod facjaty ${ }^{\mathrm{cv}} \mathrm{z}$ kruchtą drewnianą i porządną, mającą dwa schowania, małe z kruchtą murowaną sklepioną, w której kamienna posadzka a marmurowa kropielnica, drzwi do kościoła podwójne - do zamku jedne, drugie do kłódek; posadzka w wielkim chórze w tafle kamienna, w małym marmurowa, z której wnijście do dobrego bez okna grobu z nadkryciem kamiennym. Ściany dosyć przystojnie malowane; okien siedm, bez jednego dobrych; podsybitk $\mathrm{a}^{\mathrm{cw}} \mathrm{w}$ dużym chórze drewniana, wybita płótnem nadpsutym i malowana, mały zaś sklepiony chór i malowany, wiązania dobre; dach nad wielkim chórem i kruchtami dobry, nad którym kopułka z sygnaturką, nad małym i zakrystią zła dachówka. Ołtarze trzy: wielki na trzech gradusach ${ }^{\text {cx }}$ kamiennych $\mathrm{z}$ mensa konsekrowaną drewniany, $z$ ciborium ${ }^{\text {cy }}$ dosyć przystojny malowany niebiesko i złocony, obraz Matki Boskiej Narodzenia mający. Po bocznych dwa na dwóch gradusach $\mathrm{z}$ mensami konsekrowanemi drewniane, wielkiego wzorem malowane (w jednym świętej Anny, w drugim świętego Mikołaja) obrazy, przy których powyżej tęcza równie z ołtarzami malowana. Chrzcielnica [z] czarnego marmuru z mosiężnym przykryciem. Szafka na olej święty $\mathrm{z}$ żelaznemi w murze drzwiczkami umieszczona; ambona w marmur malowana i złocona gustownie. Chór w marmur ${ }^{58}$ malowany snycerskiej roboty dobry, z pozytywem o głosach ośmiu ${ }^{59}$, malowanym czarno i złoconym; konfessyonał jeden; stalla dwoiste wielkie żółto malowane, małe niemalowane jeszcze; ławek przęseł dwa, pod chórem stallów dwa żółto malowane. Zakrystia murowana: drzwi z zamkami dwoma ${ }^{60}$, posadzkę z cegły, okno z podwójną kratą i złe szafy mająca, cała sklepiona i malowana. Dzwonnica na podmurowaniu drewniana, dwa dzwony mająca; cmentarz otoczony parkanem niezbyt nadpsutem. Kościół ten ma odpusty na Narodzenie Najś[więtszej] Panny, na święty Joachim ${ }^{\mathrm{cz}}$, na świę[tą]

${ }^{\mathrm{cu}}$ W Liber beneficiorum rzeczywiście brak jest wzmianki o konsekracji. (Zob. J. Długosz, Liber beneficiorum dioecesis Cracoviensis, w: J. Długosz, Opera omnia, t. 8, oprac. A. Przeździecki, Kraków 1864, s. 147-148; tenże, t. 7, s. 170).

${ }^{\mathrm{cv}}$ In. fasada.

${ }^{\mathrm{cw}}$ In. podsiębitka, podsufitka lub podbitka, czyli wykończenie spodniej części okapu.

${ }^{\mathrm{cx}}$ In. na stopniach.

${ }^{c y}$ Zapewne chodzi o tabernakulum.

${ }^{c z}$ Wspomnienie św. Joachima przypada na dzień wspomnienia św. Anny, czyli 26 lipca.

${ }^{58} W$ oryginale: marmor.

${ }^{59} \mathrm{~W}$ oryginale: ośmią.

${ }^{60} \mathrm{~W}$ oryginale: dwiema. 


\section{[29]}

Annę, na poświęcenie kościoła ${ }^{\mathrm{da}}$ i czterdziestogodzinny ${ }^{\mathrm{db}}$. Relikwie: świętej Anny, świętego Jana Kantego i Młodzianków ${ }^{\mathrm{dc}}$.

$\underline{\text { Stan Fary }}^{61}$

Zamyka w sobie wsi siedm i pół: Zielonki, Tonie, Witkowice, Górka, Bibice, o małe pół mili z Wolą Zachariaszowską Garlice i część jedną Pękowic. Dusz religii katolickiej rzymskiej $1700 \mathrm{w}$ ogólności, a do wielkanocnej w roku 1783 1216 było spowiedzi; w roku zaś 1782 chrztów 66, ślubów 17, pogrzebów 53; nad jednych żydów 17 po karczmach i browarach żadnych dyssydentów nie masz. Tylko pod tą farą [we] wsi Witkowicach jest kaplica ${ }^{62} \mathrm{w}$ ogrodzie, przez WJX. Chryzostoma z Bodzentów ${ }^{\mathrm{dd}}$ gnieźnieńskiego i krakowskiego kanonika $\mathrm{w}$ ośmiogran ${ }^{\mathrm{de}}$ wymurowana oraz funduszem na kapelana ubogacona, co zaświadcza $\mathrm{w}$ ścianie nade drzwiami umieszczona tablica w murze marmurowa roku śmierci jego 1678 dnia 2 kwietnia. Ta [kaplica] pod tytułem świętej Maryi Magdaleny, na które święto ${ }^{\mathrm{df}}$ odprawia się przez wielu kapłanów nabożeństwo przy bardzo licznym zgromadzeniu ludu. Ma wnijście od zachodu jedno, z podwójnemi do zamku i antabamidg drzwiami, przy którym kruchta $\mathrm{z}$ dwojgiem drzwi na zachód i południe drewniana, umalowana, porządna, mająca małą marmurową wmurowana w ścianie kropielnicę. Posadzka w tej kaplicy w tafle kamienna; mury w wyśmienitym utrzymywane porządku; okien w ołów cztery oprawnych; podsybitka gruntowna umalowana, drewniana; wiązanie gruntowne z nadpsutym dachem, nad którym kopuła w perspektywę z oknami szklanemi przystojna. Ołtarz na dwóch gradusach, jednym kamiennym, drugim drewnianym ${ }^{63}$, z mensą mającą poniżej osobę Maryi Magdaleny w grobie złożonej, i mocno umieszczony portatyl ${ }^{\text {dh }}$; mały, drewniany, przystojny, niebiesko malowany ze słupami czerwonemi złote mającemi żyłki, w którym obraz Pana Jezusa Ukrzyżowanego, antepedium zaś na płótnie malowane.

da Czyli wspomniany wcześniej w wizytacjach dies dedicationis.

${ }^{\mathrm{db}}$ Tzn. w tlusty czwartek, kiedy rozpoczynało się czterdziestogodzinne nabożeństwo.

dc Relikwiarze te zostały skradzione wraz z innymi kościelnymi kosztownościami w 1846 roku. (APZ, Księga zawierająca spis sprawionych rzeczy do kościoła w wsi Zielonki oraz nakłady wyłożone na reparacją budynków plebańskich, s. 3, Kronika parafialna, t. 1, s. 50-51).

de In. o kształcie ośmioboku.

${ }^{d f}$ Wspomnienie św. Marii Magdaleny przypadało wtedy, kiedy dziś, tzn. 22 lipca.

dg Antaba, czyli ruchomy lub stały uchwyt przymocowany do drzwi, petniąca również rolę kolatki.

dh Portatyl, in. przenośny ottarzyk, czyli kwadratowa plyta kamienna wyposażona $w$ drewniane drzwiczki i uchwyty do przenoszenia. Na ptycie znajdowała się odciśnięta lakowana pieczęć biskupa, informacje o dacie konsekracji, a także imiona świętych, których relikwie znajdowaty się $w$ portatylach.

${ }^{61}$ W oryginale podana fraza podkreślona podwójna kreska.

${ }^{62}$ W oryginale podana fraza podkreślona pojedyncza kreska.

${ }^{63}$ Uwspótcześniono szyk. W oryginale: Ołtarz na dwóch innym kamiennym drugim drewnianym gradusach. 


\section{Inwentarz Sprzetów Kaplicy $^{64}$}

Kielich z pateną srebrny, cały wyzłocony ${ }^{65}$, od fundatora kaplicy dany ${ }^{\text {di }}$. Ornat biały, nowy, z francuskiej w kwiaty materii, z galonem złotym i należytościami. Humerał; alba z krosienkową ${ }^{\mathrm{dj}}$ koroną; pasek; obrusów na ołtarze trzy; ręczników dwa;

\section{[30]}

korporałów dwa; puryfikaterzów trzy; mszał nowy in $\underline{4-t o}^{66}$ jeden; lichtarze 4 drewniane, błękitne; krucyfiks drewniany, malowany; pulpit pod mszał drewniany; kanon wszystek; lampa mosiężna na środku wisząca; dzwonek 1; ampułek para szklanych; puszka blaszana na hostye; w framugach drewniane, bielone statuy czterech ewangelistó ${ }^{67}$; obraz w ścianie duży i dobrze malowany, wskrzeszenie reprezentujący Łazarza, pod którym do siedzenia ławka malowana, a obraz naprzeciw wyrażający świętą Magdalenę w domu faryzeusza nogi Zbawiciela namaszczającą, pod którym szafa malowana z szufladami pięcioma ${ }^{68}$, antabkami i zamknięciem na ubiór do sprawowania Najś[więtszej] Ofiary; nad drzwiami mniejszy obraz wyrażający Jezusa Chrystusa w postaci ogrodnika zjawiającego się świętej Magdalenie. Ta kaplica jako i wieś do prześwietnej kapituły należy, której regentem jest WJX. Walenty Pruskidk, kanonik katedry krakows[kiej].

Ius collationis ${ }^{\mathrm{dl}}$ plebanii należy do Kolegium Większego Akademii Krak[owskiej] przez ustąpienie kamienicy ${ }^{69}$ Zerwikaptur zwanej $^{\mathrm{dm}}$ w katedrze krakows[kiej] w roku $1531^{70}$ dnia 23 czerw[ca].

di Tj. od Jana Chryzostoma Bodzenty.

dj Krosienko, czyli mała ramka, na której rozpina się tkaninę do haftowania.

dk Józef Walenty Pruski herbu Prawdzic - ur. 1714 roku, kanonik prebendy Wawrzyniecka, kanonik przemyski i kanonik krakowski od 29 IV 1740 roku. Petnit postuge w dekanacie Skawina kościót parafialny pw. Wszystkich Świętych we wsi Sulkowice (Sulikowice) od 1745-1748, a także w dekanacie Zawichost - kościót parafialny pw. śś. Piotra i Pawła Apostołów we wsi Bidziny (Będziny) od 1744-1782 i kościót parafialny pw. Trójcy Świętej w mieście Tarłów od 1752-1765. Zmart 2 II 1798 roku. (Szczepaniak, Katalog parafii, s. 2; tenże, Spis prepozytów i plebanów, s. 144, 355, 370; tenże, Spis prałatów i kanoników, s. 19, 22; tenże, Nekrologium, s. 155).

${ }^{d l}$ Kolator, czyli patron wsi, a także znajdujacego się w niej kościoła, który troszczyt się finansowo o światynię. W zamian miat zapewnione miejsce przy ołtarzu, w tzw. ławkach kolatorskich.

${ }^{\mathrm{dm}}$ Kamienica ta nadal stoi w Krakowie przy ulicy Grodzkiej 57.

${ }^{64}$ W oryginale podana fraza napisana większymi literami oraz podkreślona podwójna kreska.

${ }^{65}$ Uwspótcześniono szyk. W oryginale: cały wyzłocony srebrny.

${ }^{66}$ W oryginale podana fraza podkreślona pojedyncza kreska.

${ }^{67}$ Uwspótcześniono szyk. W oryginale: statuy czterech Ewangelistów drewniane bielone.

${ }^{68}$ W oryginale: pięcią.

${ }^{69}$ W oryginale: kaminicy.

${ }^{70}$ W oryginale zapisano błędny rok 1551 . 


\section{Inwentarz sprzetów kościoła $^{71}$}

Srebro. ${ }^{72}$ Monstrancja $\mathrm{w}$ promienie pozłocista; puszka na Najświę[tszy] Sakrament takaż; puszeczka mała, $\mathrm{z}$ patenką $\mathrm{w}$ środku ${ }^{73}$ złocistą, do chorych przerobienia potrzebuje. Kielichów cztery z patenami wyzłoconych, prócz jednego tylko w środku złoconego. Kielich mosiężny $\mathrm{z}$ pateną złocony auszpurskiejdn roboty. Krzyż z czteroma serafinami ${ }^{\text {do }}$ wyzłoconemi; turybularz z łódką i łyżeczką. Relikwiarz świętej Anny mosiężny, pobielany, drugi świętego Jana Kantego, trzeci Młodzianków i obraz N[ajświętszej] Panny takiż z parą ampułek i tacą, z lampą $\mathrm{z}$ lichtarzy parą jedną, $\mathrm{z}$ podwójnemi rurkami - wszystko to mosiężne pobielane.

Mosiądz. ${ }^{74}$ Turybularz mały z łódką blaszaną; lamp dwie; lichtarzy cztery.

Miedź $^{75}$. Kociołek w chrzcielnicy, drugi na święconą wodę.

${\underline{\text { Cyna }^{76}}}^{6}$. Lawaterz z misą; naczynia na Olej Święty

\section{[31]}

na jednym sedesie potrójne, nadto dwa do chorych; ampułek para z tacą; nalewka ${ }^{\mathrm{dp}}$; lichtarzy sześć; dużych dzbanuszków para.

Ornaty $^{77}$ Białe. 1mo. Parterowyd $\mathrm{w}$ kwiat różny srebrny, z kompanką szychową $^{\mathrm{dr}}$, $\mathrm{z}$ należytościami. 2do. Rojowy ${ }^{\mathrm{ds}}$ nowy ze słupem ${ }^{\mathrm{dt}} \mathrm{w}$ kwiaty parterowym, $\mathrm{z}$ kompanką szychową ${ }^{78}$, $\mathrm{z}$ należytościami. 3tio. Haftowany w różne kwiaty z szychowym galonkiem ze stułą i manipularzem ${ }^{\text {du }}$. 4to. Kitajki ${ }^{\mathrm{dv}}$ w paski zielone z kompanką szychową i należytościami. 5to. Rojowy ze słupem w kwiaty różne haftowanym $\mathrm{z}$ kompanką szychową i należytościami 6to. Lamowy ${ }^{\mathrm{dw}}$

dn In. augsburskej roboty.

do Serafin, czyli anioł najwyższej hierarchii, gorejacy wieczna miłościa do Boga. W ikonografii serafini przedstawiani jako promieniste serca z płomienistymi skrzydłami lub jako młodzieńcy z sześcioma parami skrzydeł o kolorze czerwonym lub purpurowym.

dp In. tyżeczka do ampułek.

da Parter, czyli cenna tkanina, material na szaty liturgiczne.

dr Szych, czyli typowy żydowski ornament w ksztatcie ażurowych kóteczek, przypominajacych cekiny.

${ }^{\mathrm{ds}}$ Roja, czyli kosmata tkanina wetniana, charakterystyczna dla Krakowa.

dt In. kolumna, pionowy pas zdobiacy ornat.

du Manipularz, czyli przepaska przypominająca mała stułę. Zawieszana na przedramieniu ręki lewej, będaca w tym samym kolorze, co ornat i stuła.

${ }^{\mathrm{dv}}$ Kitajka, czyli jedwabna tkanina, tkana splotem płóciennym z przędzy.

${ }^{\mathrm{dw}}$ Lama, czyli jedwabna tkanina gładka, rzadziej wzorzysta z wąkimi pasami złotej lub srebrnej folii.

${ }^{71}$ W oryginale podana fraza napisana większymi literami oraz podkreślona podwójna kreska.

${ }^{72}$ W oryginale podana fraza podkreślona pojedyncza kreska.

${ }^{73}$ W oryginale: wsrzod.

${ }^{74}$ W oryginale podana fraza podkreślona podwójna kreska.

${ }^{75}$ W oryginale podana fraza podkreślona pojedyncza kreska.

${ }^{76}$ W oryginale podana fraza podkreślona pojedyncza kreska.

${ }^{77}$ W oryginale podana fraza podkreślona podwójna kreska.

${ }^{78}$ Uwspótcześniono szyk. W oryginale: 2 do. Rojowy z słupem w kwiaty parterowym z kompanką szychową. 
z szychowym galonkiem i należytościami odmiennemi. 7mo. Tabinowy ${ }^{\mathrm{dx}}$ z szychowym galonkiem ze stułą i manipularzem odmiennemi. 8vo. Morowy ${ }^{\mathrm{dy}} \mathrm{zły}$ ze stułą i manipularzem ${ }^{79}$ odmiennemi $^{80}$. 9no. Adamaszkowy ze słupem w różne haftowanym kwiaty z jedwabną frandzelką ze stułą i manipularzem styranemi. 10 mo. Tercynelowy ${ }^{\mathrm{dz}}$ niby $\mathrm{z}$ lamy ze słupem czerwonym $\mathrm{z}$ prostą szychową koronką, ze stułą i manipularzem odmiennemi, sterany. 11. Adamaszkowy $\mathrm{z}$ zielonym $\mathrm{w}$ kwiaty słupem $\mathrm{z}$ stułą i manipularzem odmiennemi $\mathrm{z}$ szychową jedwabną kompanką.

Czerwone $^{81} 1 \mathrm{mo}$. Adamaszkowy z zieloną i żółtą kompanką jedwabną, z stułą i manipularzem. 2do. Atłasowy ze słupem zielonym, ze stułą i manipularzem. 3tio adamaszkowy z kompanką, ze stułą i manipularzem. 4to. Tabinowy z kompanką szychową, ze stułą i manipularzem. 4to. Tabinowy z kompanką szychową, ze stułą i manipularzem. 5to. Tabinowy w lamę ze słupem w paski błękitnem, z kompanką szychową jedwabną, ze stułą [i] manipularzem. 6to. Morowy z kompanką szychową nadpsuty, ze stułą i manipularzem.

Fioletowe $^{82}$. 1mo. Tercynelowy z kompanką żółtą szychową i manipularzem tylko. 2do. Złotogłowowy ${ }^{\text {ea }}$ ze słupem haftowanym, ze stułą i manipularzem nadpsuty odmiennemi. 3tio. Grodetorowy $\mathrm{y}^{\mathrm{eb}} \mathrm{z}$ białym parterowym słupem, z kompanką białą jedwabną, ze stułą i manipularzem. 4to. Aksamitny ${ }^{\mathrm{ec}}$ ze słupem czerwonym, kompanką szychową i manipularzem tylko. 5to. Adamaszkowy $\mathrm{z}$ białą

\section{[32]}

kompanką jedwabną, ze stułą i manipularzem. 6to. Adamaszkowy z ciemnym lamowym słupem, z kompanką szychową, jedwabną, bez wszelkich należytości.

$\underline{\text { Zielone }}^{83}$. $1 \mathrm{mo}$. Adamaszkowy ze słupem czerwonym, kompanką szychową, ze stułą i manipularzem. 2do. Adamaszkowy z żółtą kompanką, ze stułą i manipularzem. 3tio. Lamowy ze słupem czerwonym obwiedzionym srebrną kompanką, a boki szychową, ze stułą i manipularzem. 4to. Lamowy ze słupem szychowym z przodku zielonej materii, ze stułą i manipularzem. 5to. Tureckiej w lamę materii, ze słupem czerwonym ze stułą i manipularzem odmiennemi.

\footnotetext{
${ }^{\mathrm{dx}}$ Tabin, czyli tkanina na szaty liturgiczne, rodzaj kitajki.

dy Mora, czyli tkanina jedwabna lub wetniana o mieniacym się deseniu w ksztalcie prążków.

dz Tercynela, czyli droga tkanina podobna do aksamitu, często z wzorem kwiatowym.

ea Zlotogłów, czyli tkanina jedwabna ze złotymi nićmi, rodzaj lamy.

eb In. gredyturowy, czyli wykonany z ciężkiego jedwabiu francuskiego.

ec Aksamit, czyli tkanina bawetniana z pętelkowa okrywa włókienną: jedwabna, wetnianą lub

${ }^{79}$ Uwspółcześniono szyk. W oryginale: Morowy z stułą i manipularzem zły odmiennemi.

${ }^{80}$ W oryginale $w$ wyrazie tym widać przekreślona duża literę $\mathrm{S}$.

${ }^{81}$ W oryginale podana fraza napisana większymi literami oraz podkreślona podwójna kreska.

${ }^{82}$ W oryginale podana fraza napisana większymi literami oraz podkreślona podwójna kreska.

${ }^{83}$ W oryginale podana fraza napisana większymi literami oraz podkreślona pojedyncza kreska.
} lniana. 
Czarne $^{84}$. 1mo. Aksamitny z białym jedwabnym galonkiem i należytościami. 2do. Tercynelowy $z$ białą szychową kompanką, ze stułą i manipularzem 3tio. Aksamitu strzyżonego $\mathrm{z}$ źółtym atłasowym słupem $\mathrm{z}$ szychowym białym galonkiem, ze stułą i manipularzem. 4to. Aksamitu strzyżonego z białą jedwabną kompanką, ze stułą i manipularzem. 5to. Morowy ze słupem w paski błękitnym, $\mathrm{z}$ galonkiem jedwabnym i styranemi stułą, manipularzem.

Welów białych z palkami i bursami dziewięć, czerwonych 4, fioletowych 4 zielonych 3, czarnych 3.

Kapy. ${ }^{85} 1 \mathrm{mo}$. Biała parterowa, $\mathrm{z}$ bokami i szczytem w złote kwiaty czerwonemi, z kompanką szychową, z srebrnemi haczykiem jednym i dwiema haftkami. 2 do. Fiołkowa parterowa $z$ szychowym białym galonkiem. 3tio. Czarna gęsiej skóry z bokami i szczytem parteru błękitnego i szychowym białym galonkiem.

Firanki ${ }^{86} \mathrm{Z}$ passyi brackiej ${ }^{\text {ed }}$ zielone jedne; czarne jedne; różnych z ołtarzy par sześć; firanka, czyli sukienka na puszkę.

Antepediów starych w różnych kolorach cztery, drewnianych malowanych $\mathrm{c}[\mathrm{z}]$ tery.

Bielizna ${ }^{87}$ Ręczników 14. Humerałów 9. Alba płótna szwabskiego z koronkami podszytymi żółtą kitajką ${ }^{88}$, szerokiemi; alb[y] dwie rąbkowe z koronkami żółtą podszytemi kitajką. Alba sztuczkowa z szychowemi i czer-

\section{[33]}

woną podszytemi kitajką koronkami. Alb[y] dwie rąbkowe z koronkami powszechnych trzy, korporałów 31. Putyfikaterzów 39. Obrusów 4, a szytych różnie z tuwalniami 31. Ręczników do lawaterza 6. Umbraculu[m] gazowe ${ }^{\mathrm{ee}}$ komży d[1]a księży 4, dla dzieci komeżek 4.

Inne sprzety ${ }^{89}$. Sukien na gradusy czerwonych 3 ; kobierzec turecki; całun; płócien na ołtarze 3; pasków włóczkowych 6; pasyjek na ołtarze 4, dużych 3 . Tabernakulum parterowe; chorągiew nowa adamaszku zielonego, druga stara adamaszku czerwonego, trzecia czerwona kałamajkowa ${ }^{\text {ef }}$, czwarta i piąta białe, szósta i siódma szkotowe; obrazów do noszenia dwa; relikwiarzy szklanych cztery. Portatyl. Zwierciadeł 2; lusterek 2; obrazów N[ajświętszej] P[anny] Częstochows[kiej] 3; biretów 3. Szkaplerzy par 14. Baldachim z firankami białemi, lichtarzy drewnianych dużych posrebrzanych 6 , pomniejszych takich 12 , błękitno malowanych 6. Ampułek szk[1]anych par 4; cieniów 10; dzbanuszków glinianych par 4. Lamp kopa i pół, kanonów z pobocznemi 3. Koło żelazne jedno;

\footnotetext{
ed Chodzi o Bractwo św Anny. Zob. przypis 32.

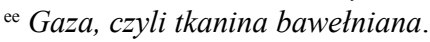

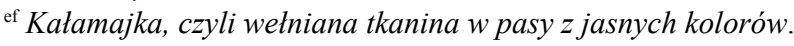

${ }^{84} \mathrm{~W}$ oryginale podana fraza napisana większymi literami oraz podkreślona podwójna kreska.

${ }^{85}$ W oryginale podana fraza napisana większymi literami oraz podkreślona pojedyncza kreska.

${ }^{86}$ W oryginale podana fraza napisana większymi literami oraz podkreślona pojedyncza kreska.

${ }^{87}$ W oryginale podana fraza napisana większymi literami oraz podkreślona podwójna kreska.

${ }^{88}$ Uwspótcześniono szyk. W oryginale: żółtą podszytymi kitajką.

${ }^{89}$ W oryginale podana fraza napisana większymi literami oraz podkreślona podwójna kreska.
} 
obrazów 4: świętych Józefa, Wojciecha, Jana Kantego i Maryi Wniebowzięcia. Lasek malowanych 5. Kap zielonych brackich 8, białych 12. Krzesło; pulpitów 3 drewnianych, jeden dobry dwa popsute. Skrzynia na światło z zamkiem.

Ksiażki. ${ }^{90}$ Mszałów 4, z których jeden dobry, trzy nadpsute; z żałobnych 3; agendy dwie duże, mała jedna; graduał z psałterzem złe; antyfonarz; ewangeliki; metryki chrztu, ślubu i pogrzebu od roku 1656 poczynają się i są ciągłe do roku $1783^{\text {eg. }}$.

\section{Summaryusz Dokumentów ${ }^{91}$}

1440. Liber beneficioru[m] ${ }^{\text {eh}}$; Liber retaxationu[m] $]^{\text {ei }} ; 1531$ dnia 23 czerwca w kapitule katedralnej krak[owskiej] ustąpienie Akademii prawa prezentowania dekret $^{\mathrm{ej}}$; 1622 między plebanem i prokuratorem zamku krak[owskiego] o dziedzictwo ogrodu w Zielonkach w sobotę przed niedzielą Laetare ${ }^{\mathrm{ek}}$ królewski w Warszawie dekret; 1694 dnia 20 października względem dziesięciny wsi Tonie kompozycji kopia; 1700 dnia 25 czerwca Augusta Drugiego króla polskiego na grunt przywilej; 1727 dekret wizytyel; 1748 dekret wizyty ${ }^{\mathrm{em}}$; Wizyta Kaźmierskiego ${ }^{\mathrm{en}}$.

\section{[34]}

\section{Stan ekonomiczny ${ }^{92}$}

Plebania stara na piwnicy murowanej zamyka w sobie izbę wielką $\mathrm{z}$ piecem i kominem, i czworo ${ }^{93}$ z prętami okien żelaznemi, przy której komnata długości z izbą, z jednym takimże oknem; $\mathrm{z}$ tej idąc mała izdebka $\mathrm{z}$ kominem, piecem i oknem, dalej kuchenka - to pod gontem dobrym. Naprzeciw przy cmentarzu budynek $\mathrm{w}$ roku 1779 od rządcy postawiony na murowanej piwnicy, zamyka w sobie na dole wozownię, nad którą spichlerz z sąsiekami, na dole izbę z kominem [i] piecem, komnatę, sionkę, a nad tą po schodach idąc jest to samo - sionka,

eg Odrestaurowane części ksiag metrykalnych z tych lat obecnie sa przechowywane w archiwum parafialnym.

eh (Długosz, Liber beneficiorum, t. 7-9). Z pewnościa w Zielonkach przechowywano wyciag z ksiag Dlugosza dotyczacy tej parafii. Prawdopodobnie tożsamy z tenże, t. 8, s. 147-148.

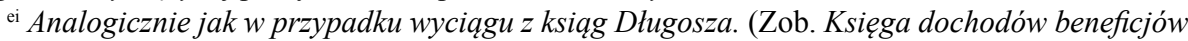
diecezji krakowskiej z roku 1529 (tzw. Liber retaxationum), oprac. Z. Leszczyńska-Skrętowa, Wrocław-Warszawa-Kraków 1968, s. 48, 173, 296, 320, 341).

${ }^{\text {ej }}$ Dokumentu tego nie ma już w parafii. Znajduje się natomiast $w$ AUJ, fasc. 301.

ek Niedziela Laetare, czyli czwarta niedziela Wielkiego Postu.

${ }^{\text {el }}$ AKMKr, AV 23, s. 37; AVCap 61, s. 30v.

${ }^{\text {em }}$ AKMKr, AV 29, s. 101-102.

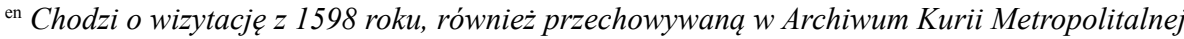
w Krakowie i prezentowana w niniejszej pracy.

${ }^{90}$ W oryginale podana fraza napisana większymi literami oraz podkreślona podwójna kreska.

${ }^{91} W$ oryginale podana fraza napisana większymi literami oraz podkreślona podwójna kreska.

${ }^{92}$ W oryginale podana fraza napisana większymi literami.

${ }^{93}$ W oryginale: cztery. 
izdebka z kominem, piecem i komnatą, u których wszystkich nowe francuskie zamki, a u okien pręty żelazne. Idąc $\mathrm{z}$ tej izdebki ganek, przez ten idąc narożnik na nowej piwniczce murowanej mający w sobie na dole i na górze po izdebce $\mathrm{z}$ oknami.

Folwark $^{94}$ mający po prawej izdebkę z piecem i komnatę, w których po oknie; po lewej ręce piekarnia z piecem piekarskim i komora - to potrzebuje przyciesi i dachu. Obora z chlewami i okołem niewielka, poszycia wyciąga, przy której budynek stary, w którego środku jest stajnia na konie mająca z obydwóch stron komórki, nad stajnią spichlerz, ten budynek w przyciesiach od rządcy podwleczony i w dachu odmieniony, za którym sad i ogród gospodarski, w którego końcu stodoła $\mathrm{z}$ boiskiem o dwóch zapolach i szopa niedawna, przy cmentarzu dom na piwnicy murowany, w którym izdebka z komnatą i kuchenką. Za cmentarzem trochę opodal jest chałup dużo nadpsutych dla starości pięć, w których dziewięć chałupników, bez żadnego gruntu, przeto dzień tylko w tydzień wszystkich robiących, z tych w jednej organista się mieści, w drugiej szynk, za czerw[onych] zł 12, zaarendowany po upadłej karczmie.

Inwentarz ${ }^{95}$ Inwentarza ekonomicznego tak w koniach lub bydle, jako i w narzędziach gospodarskich żadnego nie zastałem ${ }^{96}$ prócz wozu starego i na nic zdatnego. Gdy bowiem przez poprzednich plebanów zawsze przez dzierżawę to beneficjum chodziło, dzierżawcy sobie sprzężaje i narzędzia gospodarskie mając, bez tych plebania dostała ${ }^{97}$ się, jako widzieć $\mathrm{w}$ inwentarzu a[nn]o 1764, zaraz $\mathrm{z}$ początku odebranego beneficjum zieloneckiego per notarium apostolicum

\section{[35]}

spisanego, może jednak i obiecuje teraźniejszy pleban cośkolwiek zostawić.

Grunta: ${ }^{88}$ te nad rzeką Prądnik ${ }^{99}$ leżące corocznie i po kilka razy wylewie są podległe, z których pleban dziesięcinę capellano sancti Vladislai in Arce Crac[oviensi] przez pół wydawać musi, a za tym pokazuje się, że kościół ten żadnego gruntu posażnego nie ma, gdyż tylko stajanie za kościołem wolne do wytyczy. Siana jak jest in „Libro beneficiorium” wyrażone ${ }^{\mathrm{eo}}$, tak dotąd prawdzi się, że tylko trzy fury, a czasem i mniej zbiera się, gdy powódź pomienionej rzeki napadnie.

Wysiew $^{100}$. Co do wysiewów gruntowych, tych dla zbyt małego gruntu niewiele wychodzi, bo w roku teraźniejszym na ozimę wysiano pszenicy kor[ców] 4. miar 3. żyta kor[ców] 2, ćw[ierci] 2, miar 1, na jare jęczmienia kor[ców] 4. miar 2.

\footnotetext{
${ }^{\text {eo }}$ Por. Długosz, Liber beneficiorum, t. 8, s. 147-148.

${ }^{94}$ W oryginale podana fraza napisana większymi literami i podkreślona podwójna kreska.

${ }^{95} \mathrm{~W}$ oryginale podana fraza napisana większymi literami i podkreślona podwójną kreską.

${ }^{96}$ Końcówka wyrazu niepewna z powodu czarnego kleksu atramentowego po literze $t$.

${ }^{97}$ W oryginale skreślony wyraz mi.

${ }^{98}$ W oryginale podana fraza podkreślona podwójna kreska.

${ }^{99}$ W oryginale przekreślone zostało powtórzenie Pradnik.

${ }^{100}$ W oryginale podana fraza napisana większymi literami i podkreślona podwójna kreska.
} 
w roku zaś przeszłym wysiano pszenicy kor[ców] 3. miar 1, żyta kor[ców] 2, ćw. 2, miar 1, jęczmienia kor[ców] 3. ćw[ierci] 2, miar 1, z tego gruntu jedna część na ugór zapuszczona bywa dla paszy, której żaden pleban we wsi mieć nie może.

Dziesiecinv $^{\mathbf{1 0 1}}$. Dziesięciny $\mathrm{w}$ samych Zielonkach kościołowi temu z połowy tylko krescencji dworskiej i kilka chałup dostaje się, drugą połowę $\mathrm{z}$ niektóremi rolami bierze capellanus sancti Vladislai in arce Crac[oviense] ${ }^{\text {ep }}$. W tejże wsi w prestimonium capituli Crac[oviensis] z chłopskich gruntów połowę bierze canonicus fundi Posądza ${ }^{\mathrm{eq}}$, drugą połowę i całą dworską pleban zielonecki; w tychże Zielonkach ex certis agris bierze dziesięcinę canonicus fundi Zakrzówek ${ }^{\mathrm{er}}$, z innych zaś gruntów bierze proboszcz kościoła farnego świętego Szczepana w Krakowie. W innych wsiach tak dziesięcina idzie: w Toniach prestimonio capitulari, z dworskich gruntów bierze pleban zielonecki $\mathrm{i}$ to $\mathrm{w}$ te lata, gdy wysiew ozimny lub jary $\mathrm{w}$ tych polach będzie, więc dwa lata biorąc, w trzecim roku, gdy ugór jest, nic nie bierze, i z kilku chałupek wytyka się dziesięcina, z drugiej zaś strony kościół giebułtowski wytyka dziesięcinę. W Garlicy są dwie części - kapitulna i szlachecka. Z szlacheckiej, która jest wytyczna, bierze pleban płatna zł 200, z kapitulnej zaś regens villa ${ }^{\text {es }}$ na siebie bierze, z Woli Zachariaszowskiej i Witkowic, i Górki posessores, czyli regentes bonorum odbierają pro suo usu pomienione dziesięciny. W Bibicach, dobrach panien norbertanek zwierzynieckich, lubo z dworskich gruntów wytykać należy, ale dla wielkiego $\mathrm{z}$ dawnych lat o grunta zakłó-

\section{[36]}

cenia, temi czasy panny pozł 160 interimpłacą, pókijakafinalna ugoda nie stanie. $\underline{\text { Intrata }}{ }^{102} \mathrm{z}$ wszelkich produktów wynosi na zł 1000, odtrąciwszy jednak expens kościelną gruntową i podatki ledwie że się zostanie zł 500 na wyżywność plebana.

ep Ottarz poświęcony św. Władystawowi znajdowat się przy kolumnie prezbiterium, obok głównego ołtarza, przy grobie króla Władysława Lokietka w katedrze na Wawelu. Altaria została ufundowana po śmierci króla w 1333 roku przez jego syna i następcę tronu - Kazimierza Wielkiego. Ottarz św. Władystawa zostat zburzony w 2. pot. XVII wieku. (Kumor, Dzieje diecezji krakowskiej, s. 347-348).

eq Posadza, wieś zlokalizowana niedaleko Proszowic, przy drodze do Krakowa, parafia Koniusza. Wieś była własnościa biskupów krakowskich. Z niej (obok Boronic, Toń i Zielonek) pobierano dziesięciny stanowiace uposażenie prebendy i kanonii krakowskiej; stą: canonicus fundi Posądza (SG, t. 8, s. 842; M.D. Kowalski, Uposażenie krakowskiej kapituły katedralnej w średniowieczu, Kraków 2000, s. 112-113).

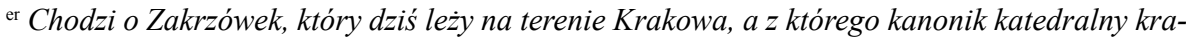
kowski czerpat dochody (Liber retaxationum, s. 296).

es Tzn. Zielonki.

${ }^{101}$ W oryginale podana fraza napisana większymi literami i podkreślona podwójna kreską.

${ }^{102}$ W oryginale podana fraza napisana większymi literami i podkreślona podwójną kreską. 


\section{$\underline{\text { Stan osobisty }}^{103}$}

J.X. Jakob Niegowieckiet świętej teologii doktor, kolegiaty świętej Anny w Krakowie dziekan, a pleban tutejszy. 1724 roku dnia 3 października urodzony; na kapłaństwo [w] 1763 roku poświęcony; [w] 1767 dnia 1 kwietnia za prezentą Kolegiu[m] Akademii Krak[owskiej] razem i na dziekanię, bo jej to jest fundusz w konsystorzu krakow[skim] instytuowany; do słuchania spowiedzi roku 1782 na lat 3 approbowany.

J.X. Jan Ziembieńskie ${ }^{\text {eu }}$ wikary; 1745 roku dnia 26 grudnia urodzony; 1769 na kapłaństwo poświęcony; 1782 dnia 21 lipca przyjął aplikację; 1782 dnia 2 grudnia do słuchania spowiedzi po okazanym odprawionych zaświadczeniem rekolekcji approbowany. Józef Katarzeńskiv ${ }^{\text {ev }}$ organista ma lat 36 wieku, a trzeci [rok] przy kościele zostaje.

\section{Dekret Wizyty $^{104}$}

Pierwsze oka na ten kościół i miejsce wejrzenie zaraz daje poznać zacność rządcy tego beneficjum nie przez jakie cudzych próśb i zasług względy, nie przez ubieganie się w uprzedzeniu zacniejszych i ludzkie przemysły, ale cnoty wiekiem dojrzałym od ludzi pobożnością i nauk biegłością najzacniejszych doświadczonej blaskiem potem $\mathrm{z}$ nadwerężeniem sił i zdrowia nad książkami i kilkadziesiąt lat z najwyższą pochwałą danemi naukami obficie wylanym szczupłą nader odpłatą do sługującego się. Tu bowiem w kościele dopełnione najwyśmienitszego pasterza widzieć obowiązki, Domu Bożego ochędóstwo i ozdoby, że nie masz co by naganie, i owszem nie masz coby nie chwalić bez ubliżenia sprawiedliwości i nie szacować. Jedna tylko rzecz oko oszukuje, zapatrzywszy się albowiem na to, co dla tego miejsca uczynił, już chór wielki dachem i posadzką opatrzywszy, już dwa relikwiarze świętego [Jana] Kantego i świętych Młodzianków oraz kielich (suto, choć z miedzi, wyzłacany), mszał nowy sprawiwszy, już kropielnicą marmurową

[37]

i sześciu na drewnie wysrebrzanemi dużemi lichtarzami Dom Boski ozdobiwszy, dzwonnicę wkoło podmurowawszy, studnię wycembrowawszy, ozdobny gmach na dwa piętra z wozownią, spichlerzem i izdebkami mieszkalnemi do kilku tysięcy kosztujący wystawiwszy, rozumiałby kto, że tysiączne ma z tego

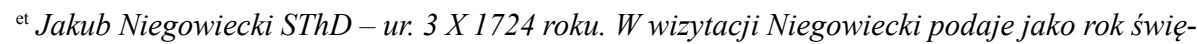
ceń kaptańskich 1763, jednak Szczepaniak w Nekrologium zaznacza, iż byto to 5 VI 1762 roku. Petnit funkcje archidiakona (12 XII 1760-1767), a następnie dziekana kapituly kolegiackiej św. Anny (1 IV 1767-1783), proboszcza w Olkuszu (3 X 1763-1767) i Zielonkach (1 IV 1767-1783). Zmart 6 X 1783 roku (APZ, Xiązka bracka, passim; Szczepaniak, Spis prałatów i kanoników, s. 95, 97; tenże, Spis prepozytów i plebanów, s. 93; tenże, Nekrologium, s. 130).

eu Jan Ziębieński (Ziębiński) - ur. w 1745 roku. Święcenia kapłańskie przyjąt w 1764 roku. W 1784 roku zostat przeniesiony na wikariat w Iwanowicach, gdzie zmart 6 XI 1788 roku (Szczepaniak, Nekrologium, s. 222).

ev Na obecnym etapie badań nie udało się odnaleźć więcej informacji o wspomnianej osobie.

${ }^{103}$ W oryginale podana fraza napisana większymi literami i podkreślona podwójna kreska.

${ }^{104}$ W oryginale podana fraza napisana większymi literami i podkreślona podwójną kreską. 
miejsca dochody, kiedy raczej ujętą sobie wygodą nawet potrzebną, te rzeczy przy uszczuplonym przez oderwanie należytości (i tę to ja jedyną upatruję dla spokojności wprawdzie $\mathrm{w}$ nieodzyskiwaniu winę, zaręczony jednak poprawy obietnicą) uskutecznił dochodzie. Z tych powodów nie śmiałbym żadnego w reparacjach czynić rozrządzenia, dopełniając jednak przepisów moich obowiązki dla przyczynienia mu przed Bogiem i ludźmi zasługi następujące tu umieszczam. W roku 1. dachówkę kościelną, gdzie potrzebuje, ponaprawia i chałupy swych poddanych wesprze. $\mathrm{W}$ roku 2. przedartą w jednym miejscu podsybitkę poprawi i zamaluje, pod folwark przyciesi przygotuje, w roku 3 . szafy zakrystii ponaprawia i przyciesi folwarku podwlecze, dach naprawi. Na koniec z aktów niniejszej wizyty przed rokiem ekstrakt wyjąć nie opuści ${ }^{\text {ew }}$. Dan w Zielonkach 20 maja 1783 roku.

\section{BIBLIOGRAFIA}

\section{Źródła}

\section{Archiwum Kurii Metropolitalnej w Krakowie (AKMKr)}

Acta visitationis (AV) 8, s. 126v-127.

Acta visitationis (AV) 23, s. 34-37.

Acta visitationis (AV) 29, s. 60-63; 97v-102.

Acta visitationis capituli Cracoviensis (AVCap) 15, s. 13-15v.

Acta visitationis capituli Cracoviensis (AVCap) 55, s. 27-37.

Acta visitationis capituli Cracoviensis (AVCap) 61, s. 27-29.

Acta visitationis capituli Cracoviensis (AVCap) 65, s. 317v-318.

Tabele Załuskiego 7 (Tabl. Zał. 7), tabela nr 83.

\section{Archiwum parafii Zielonki (APZ)}

(b. sygn.) Księga zawierająca spis sprawionych rzeczy do kościoła w wsi Zielonki oraz nakłady wyłożone na reparacją budynków plebańskich.

(b. sygn.) Kronika parafialna, t. 1 .

(b. sygn.) Xiążka bracka św. Anny w Zielonkach, R. P. MDCCLXXXV.

\section{Archiwum Uniwersytetu Jagiellońskiego (AUJ)}

fasc. 301 .

\section{Opracowania}

Brückner Aleksander, Encyklopedia staropolska, Warszawa 1990.

Bukowski Waldemar, Marszowice, w: Słownik historyczno-geograficzny województwa krakowskiego w średniowieczu, red. W. Bukowski, cz. 4, z. 1, Kraków 2006, s. 156-166.

${ }^{\mathrm{ew}}$ Rzeczywiście, wyciag z tej wizytacji przechowywano w archiwum parafialnym, o czym świadczy powolanie się na nia w kronice parafialnej w 1878 roku (APZ, Kronika parafialna, t. 1, s. 11). 
Bulak Jan, Życie codzienne w parafi Zielonki w świetle osiemnastowiecznych akt wizytacji, w: Wybrane zagadnienia z dziejów Zielonek i Bibic, red. J. Bulak, M. Zieliński, Zielonki 2018, s. 15-33.

Długosz Jan, Liber beneficiorum dioecesis Cracoviensis, w: J. Długosz, Opera omnia, t. 7-9, oprac. A. Przeździecki, Kraków 1864.

Encyklopedia wiedzy o jezuitach na ziemiach Polski i Litwy 1564-1995, oprac. L. Grzebień, Kraków 1996.

Glemma Tadeusz, Wizytacje diecezji krakowskiej z lat 1510-1570, Kraków 1946.

Główka Dariusz, Akta wizytacji kościelnych z wieków XVI-XVIII jako źródto do dziejów historii kultury materialnej. Gospodarstwo wiejskie $w$ dobrach parafialnych $w$ archidiakonacie warszawskim, w: Szkice z dziejów materialnego bytowania społeczeństwa polskiegored. M. Dembińska, Wrocław-Warszawa 1989, s. 233-254.

Katalog mikrofilmów Ośrodka Archiwów, Bibliotek i Muzeów Kościelnych przy Katolickim Uniwersytecie Lubelskim, nr 4, oprac. B.S. Kumor, Lublin 1975.

Kowalski Marek Daniel, Uposażenie krakowskiej kapituły katedralnej w średniowieczu, Kraków 2000.

Kracik Jan, Zasoby Archiwum Kurii Metropolitalnej w Krakowie, „Analecta Cracoviensia”, 9 (1977) s. 471-493.

Księga dochodów beneficjów diecezji krakowskiej z roku 1529 (tzw. Liber retaxationum), oprac. Z. Leszczyńska-Skrętowa, Wrocław - Warszawa - Kraków 1968.

Kumor Bolesław Stanisław, Dzieje diecezji krakowskiej do roku 1795, t. 1, Kraków 1998.

Kurtyka Janusz, Ksiąz Wielki, w: Słownik historyczno-geograficzny województwa krakowskiego w średniowieczu, red. F. Sikora, cz. 3, z. 3, Kraków 2000, s. 291-313.

Laberschek Jacek, Goszcza, w: Stownik historyczno-geograficzny województwa krakowskiego $w$ średniowieczu, oprac. J. Laberschek, Z. Leszczyńska-Skrętowa, F. Sikora, J. Wiśniewski, cz. 1, z. 4, Wrocław 1986, s. 811-812.

Laberschek Jacek, Grodzisko, w: Stownik historyczno-geograficzny województwa krakowskiego $w$ średniowieczu, oprac. J. Laberschek, Z. Leszczyńska-Skrętowa, F. Sikora, cz. 2, z. 1, Wrocław 1989, s. 72.

Leszczyńska-Skrętowa Zofia, Brańczyce, w: Słownik historyczno-geograficzny województwa krakowskiego w średniowieczu, oprac. J. Laberschek, Z. LeszczyńskaSkrętowa, F. Sikora, J. Wiśniewski, cz. 1, z. 4, Wrocław 1986, s. 208-209.

Leszczyńska-Skrętowa Zofia, Garlica Dolna, w: Słownik historyczno-geograficzny województwa krakowskiego w średniowieczu, oprac. J. Laberschek, Z. LeszczyńskaSkrętowa, F. Sikora, J. Wiśniewski, cz. 1, z. 4, Wrocław 1986, s. 707-709.

Leszczyńska-Skrętowa Zofia, Giebołtów, w: Słownik historyczno-geograficzny województwa krakowskiego w średniowieczu, oprac. J. Laberschek, Z. LeszczyńskaSkrętowa, F. Sikora, J. Wiśniewski, cz. 1, z. 4, Wrocław 1986, s. 726-730.

Małecki Jan Maria, Dzieje Witkowic i Górki Narodowej dawnych wsi kapituly katedralnej. Ze studiów nad przedmieściami Krakowa, Kraków 2010.

Markiewicz Tomasz, Duchowieństwo dekanatu Skała w świetle wizytacji z 1618 roku, „Archiwa Biblioteki i Muzea Kościelne”, 94 (2010) s. 79-193.

Monumenta Poloniae Historica, t. 2, oprac. A. Bielowski, Lwów 1892.

Nitecki Piotr, Biskupi Kościoła w Polsce w latach 965-1999. Słownik biograficzny, Warszawa 2000.

Pęski Adam Wiktor, Wizyta kościelna, w: Encyklopedia kościelna podtug teologicznej encyklopedji Wetzera $i$ Weltego z licznymi jej dopelnieniami, t. 31, Warszawa 1911, s. 534-538. 
Rożek Michał, Nie istniejące kościoły Krakowa, „Biuletyn Biblioteki Jagiellońskiej”, 33 (1983) s. 95-120.

Rożek Michał, Przewodnik po zabytkach i kulturze Krakowa, Kraków 1993.

Sikora Franciszek, Góra Nowa, w: Słownik historyczno-geograficzny województwa krakowskiego w średniowieczu, oprac. J. Laberschek, Z. Leszczyńska-Skrętowa, F. Sikora, J. Wiśniewski, cz. 1, z. 4, Wrocław 1986, s. 828-829.

Słownik geograficzny Królestwa Polskiego i innych krajów słowiańskich, red. F. Sulimierski, B. Chlebowski, W. Walewski, t. 1-16, Warszawa 1880-1914.

Słownik historyczno-geograficzny województwa krakowskiego w średniowieczu, cz. 1-4, Kraków 1980-2006.

Szczepaniak Jan, Katalog parafii i duchowieństwa diecezji krakowskiej 1748, Kraków 2006.

Szczepaniak Jan, Spis prałatów i kanoników kapituły katedralnej oraz kapituł kolegiackich diecezji krakowskiej (XVIII w.), Kraków 2008.

Szczepaniak Jan, Spis prepozytów i plebanów diecezji krakowskiej (XVIII w.), Kraków 2008.

Szczepaniak Jan, Katalog duchowieństwa diecezjalnego zestawiony na podstawie krakowskich ksiag święceń (1646-1789), t. 4, Kraków 2009.

Szczepaniak Jan, Duchowieństwo diecezji krakowskiej w XVIII w. Studium prozopograficzne, Kraków 2010.

Szczepaniak Jan, Nekrologium. Księża diecezji krakowskiej zmarli w latach 1749-1810, Kraków 2010.

Teka Grona Konserwatorów Galicyi Zachodniej, t. 2, Kraków 1906.

Wyżga Mateusz, Funkcjonowanie wiejskich cmentarzy parafii katolickich $w$ dobie przedrozbiorowej na przykładzie dekanatów Nowa Góra, Skała i Proszowice z okolic Krakowa, „Kwartalnik Historii Kultury Materialnej”, (2014) nr 3, s. 441-461.

\section{Netografia}

Bulak Jan, Duchowieństwo parafii Zielonki (1795-1918), w: XLV Międzynarodowe Seminarium Kót Naukowych „Koła Naukowe - Szkoła Twórczego Działania”, red. M. Gryglik, S. Skiendziul, J.E. Śliczyńska, Olsztyn 2016, s. 45-49, https:// msknolsztyn.files.wordpress.com/2016/09/tom-1-sekcja-humanistyczna-sekcjateologiczno-kanonistyczno-familiologiczna.pdf (dostęp: 17.04.2017).

Parafia w Witkowicach, http://parafiawitkowice.krakow.pl/?page_id=159, (dostęp: 08.03.2017). 


\title{
THE VISITATION RECORDS OF THE ZIELONKI PARISH (NEAR KRAKOW) OF THE 18TH CENTURY IN THE ARCHIVE OF THE METROPOLITAN CURIA IN KRAKOW
}

\begin{abstract}
Summary
The following publication presents the 18th-century visitation records of the Nativity of the Blessed Virgin Mary Parish in Zielonki near Krakow. The historic church of the 14th century was dependent for years on the Krakow Cathedral Chapter, then the Academy of Krakow (now The Jagiellonian University) and St Ann Collegiate Church. The article presents, as source editions, the three last visitation records of Zielonki before the fall of the Republic of Poland: of 1727 (AVCap 61 and AV 23), of 1748 (AV 29 and Załuski's Tables 7) and of 1783 (AV 55). These visitation books are held in the Archive of the Metropolitan Curia in Krakow (3 Franciszkańska Street). These visitations are manuscripts written in Latin and Polish with numerous Latin phrases. Only Bishop Załuski's Tables are a printed form completed with hand written information. The authors aimed to edit sources and to make them available to a wider audience. The methodology of the work focused on full forms of the abbreviated words used by the writers, spelling modernization with a view to making the text more legible, and the adding of the diacritic marks and punctuation where necessary. The authors provided the text with footnotes (source and explanatory notes) and endnotes (terminology). These editing activities comply with the rules of the historical source edition for modern texts. As a result, the authors present three full texts of the visitations along with inventories, introduction footnotes, endnotes and bibliography.

Key words: the Academy of Krakow; St Ann Chapter; Krakow Cathedral Chapter; a cathedral chapter; the Jagiellonian University; a canonical visitation; Krakow; the Polish and Lithuanian Commonwealth; Małopolska (Lesser Poland); Zielonki
\end{abstract}

